\title{
LAS ÓRDENES MILITARES EN EL SIGLO XIII CASTELLANO LA CONSOLIDACIÓN DE LOS MAESTRAZGOS
}

\author{
Carlos de Ayala Martínez \\ Universidad Autónoma de Madrid
}

\begin{abstract}
SUMARIO
I. Planteamiento.- II. La debilidad institucional del maestrazgo en la primera mitad del siglo XIII: 1. La vertiginosa sucesión de los maestres. 1.1. Orden de Santiago. 1.2. Orden de Calatrava. 1.3. Orden de Alcántara. 2. Claves explicativas. - III. Los procesos de transformación de la segunda mitad del siglo XIII: 1. El conflictivo gobierno de Pedro Ibáñez, maestre de Calatrava (1254-1267). 1.1. Crisis e inestabilidad de la orden. 1.2. Causas y manifestaciones de la crisis: el nacimiento de la mesa maestral. 2. El decisivo gobierno de Pelayo Pérez Correa, maestre de Santiago (12421275). 2.1. Contestación y revueltas en la orden. 2.2. Circunstancias explicativas. 3. Huellas de crisis durante el gobierno de García Fernández, maestre de Alcántara (1254-1284).- IV. Conclusión.
\end{abstract}

\section{Planteamiento}

Hoy día constituye un tópico hablar del siglo XIII como un período clave en la madurez de la sociedad e instituciones del Occidente cristiano. Lo es también en lo que se refiere concretamente a la Península, por cuanto en esta centuria se producen no pocos puntos de inflexión e inicios de fenómenos de cierta trascendencia. Castilla no es una excepción, y tampoco lo son, en este sentido, esas instituciones tan representativas en el panorama socio-político del reino como lo fueron las distintas órdenes militares.

"Anuario de Isstudios Medievales". 27 (1997) 
Cuando se inicia el siglo XIII las órdenes militares de origen extrapeninular, la del Temple y la del Hospital de Jerusalén, cuentan con unos 75 años de presencia en tierras leonesas y castellanas, y las órdenes hispánicas, las más recientes de Calatrava, Santiago y Alcántara, llevan participando activamente en la vida política y económica de los reinos de Castilla y León entre 25 y 30 años. Por diversas circunstancias ninguna de ellas constituyen al filo del 1200 organizaciones realmente sólidas. Sin embargo, al finalizar la centuria, todas en conjunto se nos muestran como edificios institucionales bien trabados y orgánicamente coherentes: en torno a 1300 las órdenes se proyectan como las clásicas y modélicas organizaciones religioso-militares cuya ejemplar vertebración y eficaz funcionamiento las convierten ya en codiciados objetivos de control por parte de la monarquía.

¿Qué circunstancias son las que explican esta decisiva transformación de las órdenes militares? ¿Por qué cauces se desarrolla tan positiva evolución en el transcurso del siglo XIII? A lo largo de estas páginas, y centrando nuestra atención en las órdenes de origen hispánico, intentaremos dar respuesta parcial a estos interrogantes, pero podemos adelantar ya que los cauces aludidos son básicamente dos: la creación de organigramas sólidos en cada una de las instituciones y su fundamentación en realidades espaciales jurisdiccionalmente bien integradas. Ambos cauces posibilitan y son manifestación al mismo tiempo de unas transformaciones que, en ningún caso, pueden ser disociadas del complejo marco político y social del siglo XIII en que se desenvuelven.

El siglo XIII contempla, en efecto, los primeros y decisivos pasos de las órdenes militares cara a su formal institucionalización. Al iniciarse la centuria se nos aparecen como organizaciones poco articuladas en sus contornos y menos aún en su desordenada realidad interna, organizaciones en que las figuras de maestres y comendadores a duras penas adquieren perfiles precisos en la documentación, y cuyas funciones no siempre se nos muestran bien definidas. Conforme avanza el siglo, ya desde sus décadas centrales, y con más evidencia a finales del mismo, el panorama ha cambiado radicalmente: las órdenes son en ese momento organizaciones bien vertebradas en las que las distintas dignidades e instituciones corporativas encuentran cómoda ubicación y definidas competencias en una realidad institucional coherente y sólida. El proceso de cambio hacia estos esquemas organizativos eficazmente trabados cuenta con tres manifestaciones fundamentales: progresiva institucionalización de las dignidades personales, 
desarrollo de los diferentes órganos colegiales y consolidación de los distintos mecanismos y cauces que interrelacionan a unas y otros en un todo coherente. En estas páginas vamos a ocuparnos únicamente de la primera de estas manifestaciones, y más en concreto de la institucionalización y fundamentación operativa de la más alta y representativa de las dignidades personales: la figura del maestre. Dejamos para próximos acercamientos al tema el análisis de la realidad comendataria, así como el de las otras manifestaciones del hondo proceso de transformación constitutiva que las órdenes militares viven a lo largo del siglo XIII.

\section{II.LA DEBILIDAD INSTITUCIONAL DEL MAESTRAZGO EN LA PRIMERA MITAD DEL SIGLO XIII}

Como es bien sabido, las órdenes militares hispánicas obedecen sustancialmente a dos modelos originarios: el monástico propio de calatravos y sanjulianistas - luego alcantarinos - y el secular de la inicial cofradía santiaguista. Ese divergente origen determinó que, a diferencia de lo que ocurrió en esta última, el máximo responsable de las primeras tardara algunos años - muy pocos, ciertamente- en denominarse maestre. Pero ya a comienzos del siglo XIII, y desde hacía algunas décadas, la figura del maestre constituye la indiscutible cabeza jerárquica en las tres órdenes.

\section{La vertiginosa sucesión de los maestres}

Ahora bien, si nos acercamos a la realidad histórica de los distintos maestres que se suceden en los 40 ó 50 primeros años de la centuria, no nos dejan de sorprender algunos hechos. Para empezar, el carácter llamativamente fugaz de sus mandatos y la casi sistemática finalización de los mismos mediante renuncia.

\subsection{Orden de Santiago}

El caso de la orden de Santiago resulta, en este sentido, espectacular. Desde el fallecimiento en 1184 del primer maestre, Pedro Fernández, hasta la elección en 1242 de Pelayo Pérez Correa, se sucedieron doce maestres. Todos ellos, salvo tres que murieron prematuramente en combate contra los 
musulmanes, renunciaron en vida al ejercicio de su dignidad. ${ }^{\prime}$ En efecto, tras la siempre carismática, indiscutible $y$, por tanto, vitalicia figura del maestre fundador, sus inmediatos sucesores Fernando Díaz y Sancho Fernández habían renunciado al maestrazgo en 1186 y 1195, respectivamente. ${ }^{2}$ Es muy posible que también lo hiciera el cuarto maestre, Gonzalo Rodríguez, en $1204^{3}$, e incluso el quinto, Suero Rodríguez, aunque en su

'En realidad. el establecimiento de una sucesión cronológica precisa de los maestres santiaguistas hasta Pelayo Pérez Correa ofrece no pocas dificultades. Tres son las fuentes fundamentales para su reconstrucción: el Calendario de Uclés extractado en el siglo XVI por Ambrosio Morales (Opisculos Castellanos, II. Madrid, 1793. p. 22) y utilizado por los autores del bulario de la orden para la confección de su Series Magistrorum Ordinis Militiae Sancti Iacobi (A.F. Aguado de Córdova, A.A. Alemán y Rosales y I. López Agurleta, Bullarium Equistris Ordinis S.Iacobi de Spatha, Madrid, 1719); la más antigua narración cronística sobre la historia de la orden elaborada en el siglo XV por los comendadores Orozco y Parra (PEDRo DE OROzCo y JUAN DE LA PARRA, Comendadores de la Orden de Santiago, [Primera] Historia de la Orden de Santiago. Manuscrito del siglo XV, de la Real Academia de la Historia, prólogo de Diego de Angulo, introducción. transcripción, notas y apéndice del MARQUÉS DE SIETE IGLESIAS. Badajoz, 1978, pp. 357-367); y las noticias aportadas por el cronista Rades en el siglo XVI (F. DE RADES Y ANDRADA, Chronica de las tres Ordenes y Cauallerias de Sanctiago, Calatraua y Alcantara, Toledo, 1572, reed. facs. Barcelona, 1980 Chronica de Sanctiago, fols. 16 v-31 r).

'La renuncia de Fernando Díaz presionado por Alfonso VIII para poner fin a un presunto cisma que le enfrentaba a Sancho Fernández desde la muerte del primer maestre, es noticia de Rades desacreditada por el profesor Lomax. RADES, Chronica de Sanctiago, fols. $16 \mathrm{v}-17 \mathrm{r}$; D.W. LomaX, The Order of Santiago and the Kings of León, en "Hispania", XVIII (1958), pp. 14-16. Es cierto, sin embargo, que la renuncia se produjo, y lo es también que, a modo de compensatorio retiro, recibió el monasterio realengo de San Audito, con exención jurisdiccional respecto al nuevo maestre.

El tercer maestre, Sancho Fernández de Lemos, dimitió en noviembre de 1195. De ser cierta esta fecha, recogida en la Series Magistrorum del Bulario de Santiago, no lo sería la noticia aportada por Rades en el sentido de que el maestre moriría de resultas de las heridas recibidas en Alarcos (RADES, Chronica de Sanctiago, fol. $19 \mathrm{r}$ ). El dato fue aceptado por Julio González (J. GonzÁLEZ, El Reino de Castilla en la época de Alfonso VIII, Madrid. 1960, I, p. 600) y José Luis Martín (J.L. MarTín. Orígenes de la Orden Militar de Santiago (1175-1195), Barcelona, 1974, p. 42). pero el silencio de los primeros cronistas de la Orden, Orozo y Parra, que ratifican la renuncia y el de los propios redactores del Bulario, que serían tanto en un caso como otro los primeros interesados en destacar un heróico fallecimiento de estas características, nos inclinan a ponerlo en duda. Por si fuera poco. el Calendario de Uclés, que recoge la noticia de la desaparición en combate de cerca de 20 freires. nada dice del maestre.

3Así lo afirma la Series Magistrorum del Bulario, aunque, una vez más, hemos de advertir sobre noticias contradictorias en relación a este maestre, primero de los del siglo XIII. Rades vuelve a plantear la existencia de un cisma. Gonzalo Rodríguez habria sido electo por la maror parte de los Trezes en Vcles, pero la inmediata guerra que Alfonso IX promovió contra su primo Alfonso VIII de Castilla, rompió la unidad: el maestre legítimo, ante la escandalosa alianzi anticastellana que situaba en el mismo bando a leoneses y musulmanes, colaboró activamente con el monarca castellano, y Alfonso IX, que contaba con el apoyo de algunos freires santiaguistas de sus reinos, provocó la elección entre ellos de un amtimaestre en la persona de Gonzalo Ordónez. Pronto, sin embargo, y ante el mal trato recibido por el monarca leonés, que no dudó en confiscarles sus bienes, el antimaestre y sus freires acabaron reconociendo la autoridad del legítimo maestre castellano (RADES, Chronica de Sanctiago, fol. 20 v). Una vez 
caso el margen de probabilidad es, en este sentido, bastante menor ${ }^{4}$. En cambio, pocas dudas ofrece la casi segura dimisión del sexto maestre, Fernando González de Marañón, en $1210^{5}$. El séptimo, Pedro Arias, murió sin abandonar la dignidad, pero todo apunta a que fuera como consecuencia de las heridas sufridas en la batalla de Las Navas'. Con su sucesor, el octavo maestre santiaguista, García González de $\mathrm{Arauzo}^{7}$, volvemos a encontrarnos con una renuncia, la de $1217^{8}$. También dimitiría el noveno maestre, Martín Peláez Barragán, si es que aceptásemos la versión que sobre su breve gobierno nos facilita Rades. Para el cronista la elección de Martín Peláez iría asociada a toda una operación política que explica la renuncia del anterior maestre García González. La secuencia de los hechos sería la

más, Lomax niega la historicidad de este segundo cisma asi como de los extremos de él derivados. Para empezar, el ilustre hispanista británico duda de la intervención santiaguista en la guerra castellano-leonesa de 1196-1197; Gonzalo Rodríguez, además, aparece como maestre en documentación coetánea de ambos reinos entre 1195 y 1204 -fecha esta última en que, según Lomax, se produciría su fallecimiento- y lo relativo a la generalizada confíscación de bienes santiaguistas por parte del monarca leonés, es también preciso matizarlo: el secuestro de Castrotorafe nada tuvo que ver con la actitud de la Orden en el conflicto castellano-leonés. Para Lomax, en definitiva, Gonzalo Ordóñez nunca llegó a existir, y la presencia de su nombre en listados de cronistas modernos es atribuible a una equivocada transcripción (LOMAX, art cit., pp. 17 y ss). De hecho, en la relación del Bulario aparece como Gonsalvus Rodriguez Kodorniz alias Hordoniz.

${ }^{4}$ El Calendario de Uclés señala que murió como maestre el 23 de abril de 1206. y tampoco hablan para nada de renuncia los cronistas Orozco y Parra. Es Rades quien, sin embargo, afirma que, segun se halla en antiguas escripturas, el maestre renunció a su dignidad en 1205 sin especificar razón concreta (RADES, Chronica de Sanctiago, fol. 22 v).

${ }^{5} \mathrm{La}$ existencia de un maestre llamado Sancho Rodriguez, sucesor de Suero Rodriguez, mantenida por Rades (Chronica de Sanctiago, fol. $22 \mathrm{v}-23$ r), no parece probable. Los testimonios que aduce el cronista pueden basarse en una lectura errónea de Sancho por Suero. La donación real de Gorocica de octubre de 1205, por ejemplo, figura en el Bulario de Santiago como efectuada a Suero Rodríguez y no a Sancho Rodríguez como sugiere Rades (Bulario de Santiago, p. 53); con la misma grafía lo publica J. GonzÁlez (Alfonso VIII, III, doc. 780, p. 363).

En relación a la renuncia de Fernando González de Marañón se pronuncian con claridad tanto la Series Magistrorum del Bulario como los cronistas Orozo y Parra (Orozo-PARRA, Historia de la Orden, p. 360).

'La Series Magistrorum del Bulario, apoyándose en el Calendario de Uclés, afirma que su fallecimiento tuvo lugar el 3 de agosto de 1212, y Rades sugiere sin afirmarlo que fue como efecto de las heridas recibidas en combate (Chronica de Sanctiago, fol. 24 v). Nada dicen al respecto Orozo y Parra pero afirman que la muerte le sobrevino ejerciendo su alta dignidad maestral (Orozco-Parra, Historia de la Orden. p. 361).

${ }^{7}$ Rades y con él Julio González afirman la existencia de un maestre previo, un fugacísimo sucesor de Pedro Arias llamado Pedro González de Aragón. Según los autores citados, éste moriría en el cerco de Alcaraz habiendo gobernado la orden apenas unos meses. RADES, Chronica de Sanctiago, fol. 25; J. GonzÁLEZ, Alfonso VIII, I, p. 602.

${ }^{8}$ Vid. la Series Magistrorum del Bulario. 
siguiente: Los partidarios de la proclamación del futuro Fernando III como rey de Castilla organizaron un complot para arrebatarlo de la tutela de su padre Alfonso IX; una vez proclado rey al otro lado de la frontera, el burlado monarca leonés inició toda una ofensiva contra Castilla en cuyo contexto hay que situar la elección de Martín Peláez. Ésta habría sido fruto de las presiones del rey sobre algunos caballeros santiaguistas de sus reinos para que se apartaran de la obediencia del castellano García González. Ante el cariz que tomaban los acontecimientos, éste se vio obligado a dimitir, pero la iniciativa leonesa no dio los resultados apetecidos y sería el propio Alfonso IX el que se encargaría de forzar la renuncia del maestre intruso en 1221, unos tres años después de su fraudulenta elección, provocando, de este modo, la reposición del antiguo maestre García González 9

La versión de Rades no parece ajustarse del todo a la realidad. Probablemente es cierto que el maestrazgo de Martín Peláez Barragán constituyera una primitiva manifestación de intrusismo regio en los canónicos procedimientos de elección ${ }^{10}$, y tampoco es descabellado pensar que esta última hubiera podido ser el motivo para la renuncia del legítimo maestre, lo cual encajaría bien con la necesidad de convocar un capítulo general de la orden, el de San Marcos de 1222 — segundo del que tenemos noticia-, cuando la renuncia o más bien el fallecimiento de Martín Peláez ${ }^{11}$, permitió reconducir hacia la normalidad el rumbo de la institución. Ahora bien, no parece que esa reconducción supusiera la rehabilitación del antiguo maestre García González de Arauzo, sino que se produciría el acceso de un nuevo

${ }^{9}$ Rades, Chronica de Sanctiago, fol. 26.

${ }^{10} \mathrm{La}$ primitiva crónica de la orden redactada por Orozco y Parra insiste también en el «carácter político» del nombramiento de Martín Peláez Barragán, aunque la versión que dan de los hechos difiere de la de Rades: tras la renuncia del anterior maestre, los trece se reunieron para proceder a una nueva elección, pero se produjo desacuerdo entre ellos por razón de ambiciones encontradas y ello dio oportunidad a Fernando III para inmiscuirse en el proceso y favorecer la elección de Martín Barragán que era criado suyo y portero de su cámara (OROzOPARRA, Historia de la Orden, p. 362). No resulta quizá demasiado congruente que fuera Fernando III y no Alfonso IX quien presionara para que Martín Peláez obtuviera el maestrazgo. Pese a los datos que aportan Orozco y Parra sobre su condición de miembro de la corte castellana, lo cierto que el maestre era de origen portugués y había sido comendador de Palmela. J. GonZÁLEZ, Reinado y Diplomas de Fernando III, Córdoba, 1980, I, p. 183.

"Rades es quien afirma que renunció a la dignidad maestral por presión del rey que se la había otorgado, pero hay indicios que apuntan en otra dirección, la de su muerte en combate con los musulmanes. Orozo y Parra, sin poder precisar cuándo ni dónde, sugieren que fue así, y en la Series Magistrorum del Bulario se dice literalmente: ... ad finem ann. 1221. ob. sauciat Maur. 
titular de igual nombre, García González, pero apellidado Candamio, el décimo maestre de la.orden ${ }^{12}$.

García González de Candamio también renunció al maestrazgo tras dos años de gobierno, en $1224^{13}$, y lo propio hizo en 1226 su sucesor, el onceno maestre santiaguista Fernando Pérez Chacín, que estuvo, pues, al frente de la orden apenas dos años ${ }^{14}$. En cambio, es seguro que el duodécimo maestre, Pedro González Mengo, murió en 1237 tras diez años de gobierno $^{15}$, todo un récord hasta entonces no alcanzado por ninguno de sus predecesores, exceptuando al fundador. Con su sucesor, sin embargo, volvemos a encontrarnos con una renuncia: en 1242 el decimotercer maestre, Rodrigo Íñiguez, daba paso con su dimisión ${ }^{16}$ al más largo y trascendente de los maestrazgos de nuestro período de estudio, el de Pelayo Pérez Correa, decimocuarto maestre de la orden.

La subida al poder de Pelayo Pérez Correa constituirá, según veremos, una fuente de transformaciones de muy diversa naturaleza. En relación al tema que nos ocupa ahora, se puede afirmar que a partir de entonces se invierte el curso de los acontecimientos, y de las habituales dimisiones de maestres se pasa a una permanencia vitalicia en el cargo, sólo rota excepcionalmente. En efecto, y pese a los intentos por evitarlo, Pelayo Pérez Correa murió maestre en 1275, y lo mismo ocurrió con el resto de los

\footnotetext{
${ }^{12}$ Rades no alude en ningún momento a García González de Arauzo, para él es el de Candamio el que desde 1213, y con el intervalo del intruso Martín Peláez, se halla al frente de los santiaguistas. Por su parte la Series Magistrorum del Bulario los individualiza bien, y atribuye al de Candamio condición de casado. Lomax no duda tampoco de la existencia de dos maestres del mismo nombre separados por el gobierno de Martín Peláez Barragán. LOMAX, The Order of Santiago and the Kings of León, pp. 22-23. Del mismo autor, La Orden de Santiago (1170-1275), Madrid, 1965, p. 287.

${ }^{13}$ Orozco-Parra, Historia de la Orden, p. 363. Series Magistrorum del Bularium.

${ }^{14}$ Una vez más la Historia de Orozco y Parra así como la Series Magistrorum lo atestiguan. Hay que decir, sin embargo, que para Rades en el espacio de tiempo que corresponde al gobierno de Fernando Pérez Chacín hubo en realidad dos maestres: él mismo, muerto o dimitido un año después de su elección, y Pedro Alonso, elegido en 1225 y fallecido apenas un año después. Para Lomax, en cambio. sólo se puede hablar de un único maestre en periodo tan reducido: Fernando Pérez Chacín. En realidad, la documentación da la razón al historiador y no al cronista, que gratuitamente se hizo eco de un inexistente maestre, Pedro Alonso, presunto hijo ilegítimo de Alfonso IX (RADES, Chronica de Sanctiago, fol. 27; Lomax, La Orden de Santiago, p. 287).

${ }^{15}$ Todos los testimonios apuntan en la misma dirección, aunque sólo son Orozco y Parra los que afirman que el fallecimiento se produjo en enfrentamiento con los musulmanes (OROzCOPARRA, Historia de la Orden, p. 366).

${ }^{16}$ Salvo Rades, que no la menciona, las fuentes habituales dan testimonio de esta renuncia. Vid. Lomax, La Orden de Santiago, p. 55.
} 
titulares de la orden del siglo XIII: el maestre decimoquinto, Gonzalo Ruiz Girón, murió en la desastrosa jornada de Moclín de 1280, no siendo en este sentido representativo su fallecimiento, pero sí lo fue el de su sucesor el decimosexto maestre, Pedro Núñez, muerto en 1287, el mismo año en que, meses después, moría Gonzalo Pérez Martel, decimoséptimo maestre. Algo más duradero fue en el gobierno de la dignidad el decimoctavo maestre, Pedro Fernández de Mata, que falleció al frente de la orden en 1293, y finalmente, y aunque casi con toda probabilidad también murió maestre, cabe plantearse alguna duda sobre el decimonoveno titular, Juan Osórez, al que los cronistas Orozco y Parra, y sólo ellos, consideran que hubo de dejar el maestrazgo - estamos ya en los primeros años del siglo XIV-por bien de su anima ${ }^{17}$. En adelante, muy pocos serán los maestres que renuncien o se vean obligados a ello.

\subsection{Orden de Calatrava}

La renuncia, aunque no de manera tan patente como entre los santiaguistas, es también procedimiento normal de finalización del gobierno de los maestres calatravos. Tomemos nuevamente como momento referencial la primera mitad del siglo XIII con su preámbulo de finales del XII, concretamente el período que, una vez superada la fase abacial, transcurre entre el primer maestre, don García, que aparece ya claramente documentado como tal en 1164, y la elección de Pedro Ibáñez en 1254. Contamos para esos años con una relación de trece maestres inequívocos de los que vamos a ver cómo finalizan sus respectivos mandatos.

Nada sabemos ni de la fecha precisa ni de las circunstancias de finalización del gobierno del primer maestre don García. El breve maestrazgo del segundo titular de la orden, Fernando Escaza, que lo era ya en 1169, acabó en renuncia "por ser como era muy viejo" ${ }^{18}$. Lo cierto es que en 1170 gobernaba ya la orden Martín Pérez de Siones, su tercer maestre, que acabaría renunciando al maestrazgo en $1182^{19}$, y también lo haría su sucesor el cuarto maestre, Nuño Pérez de Quiñones, en 1197 ó 1198, aunque

\footnotetext{
${ }^{17}$ Orozco-Parra, Historia de la Orden, p. 372.

${ }^{18}$ RadES, Chronica de Calatraua, fol. $17 \mathrm{r}$.

${ }^{11}$ Rades, en contra de evidencias documentales, afirma que fue esa la fecha de su muerte (RADES. Chronica de Calatraua, fol. 19 r).
} 
curiosamente le sucedería el anterior dimisionario Martín Pérez de Siones. Cuando en el transcurso de 1199 éste último renunció por segunda vez a la más alta dignidad calatrava, la orden contaba con dos exmaestres ${ }^{20}$.

El quinto titular de la institución - primero del siglo XIII- fue Martín Martínez; no llegó a renunciar al maestrazgo, pero todo parece indicar que fue desplazado del mismo $\mathrm{y}$, refugiado en las posesiones calatravas de Aragón, figura como maestre de Alcañiz en documentos de los años 1209 y 1210. Para entonces - desde 1206- la orden de Calatrava poseía un nuevo titular, su sexto maestre Rodrigo Díaz ${ }^{21}$. En realidad, no disfrutaría de muchos años de gobierno: herido en la jornada de Las Navas, renunció como consecuencia de ello al maestrazgo, y tras recomendar una nueva elección en persona capaz de proseguir la campaña iniciada contra los musulmanes, se retiró al convento central para hacer vida estrictamente religiosa ${ }^{22}$. Los inmediatos sucesores de Rodrigo Díaz, los maestres séptimo y octavo, Rodrigo Garcés y Martín Fernández de Quintana, tuvieron poco tiempo para regir la orden, falleciendo en 1215 y 1218 respectivamen$\mathrm{te}^{23}$.

En esta última fecha accede al maestrazgo el nuevo titular de la orden, Gonzalo Ibáñez, noveno maestre, sobre cuya cronología de gobierno no existe acuerdo unánime. Rades considera que estuvo al frente de la orden durante 20 años, pero lo cierto es que deja de aparecer en los documentos en 1232 , y que en 1234 y 1235 otro maestre, Fernando Pérez, figura gobernándola. O'Callaghan ha reconstruido la secuencia de los hechos y

\footnotetext{
${ }^{20} \mathrm{La}$ clarificación de todos estos sucesos y la fijación de una cronología ajustada, en J.F. O'Callaghan, Martín Pérez de Siones, maestre de Salvatierra, en "Hispania", XXII (1963), pp. 163-170, reed. en The Spanish Military Order of Calatrava and its Affiliates, Londres, 1975, II, pp. 3-6.

${ }^{21}$ Según Rades, Martín Martínez habría acudido a Alcañiz donde le sorprendió la muerte en 1206, siendo elegido para sucederle el comendador mayor Rodrigo Díaz, que venía ejerciendo la lugartenencia del maestre en Castilla cuando éste partió a Aragón (RADES, Chronica de Calatraua, fol. 23 r). Los documentos parecen indicar otra cosa: J.F. O'CALLAGHAN, The Affiliation of the Order of Calatrava with the Order of Cîteaux, en «The Spanish Military Order of Calatravan, I, p. 287; I.J. DE ORTEGA Y COTES, J.F. ÁlvaREZ DE BAQUEDANO Y P. DE ORTEGA ZÚÑIGA Y ARANDA, Bullarium Ordinis Militiae de Calatrava..., Madrid, 1761 (ed. facs. Barcelona, 1981), pp. 40-42. Cfr. C. LALIENA CORBERA, Sistema social, estructura agraria y organización del poder en el Bajo Aragón en la Edad Media (siglos XII-XV), Teruel, 1987, p. 120.

22RADES, Chronica de Calatraua, fol. 30 v.

${ }^{23}$ Ibid., fols. 32 v y $34 \mathrm{r}$.
} 
ofrece una cronología convincente ${ }^{24}$ : Gonzalo Ibáñez moriría en 1232 y un nuevo maestre, Fernado Pérez, décimo en la sucesión de la orden, accedería entonces a la más alta dignidad de la institución; algunos testimonios permiten suponer que la toma de posesión de su maestrazgo pudo revestir ciertas características de irregularidad; en cualquier caso, su fallecimiento a finales de 1237 o principios de 1238 daría paso al onceno maestre calatravo, Martín Ruiz, que ya figura como tal en los primeros meses de este último año.

Aunque en principio nada hay que objetar a la explicación de O'Callaghan, sí cabe al menos plantearse la duda de si el tránsito de maestrazgos tanto en 1232 como en 1238 se produjo por fallecimiento del anterior titular o por desplazamiento del mismo en el cargo. El ilustre historiador norteamericano no se plantea la duda pero no nos faltan testimonios que nos permiten caracterizar todo el período como de especialmente crítico para la historia interna de la orden: Rades afirma que el propio acceso de Gonzalo Ibáñez en 1218 no había sido en concordia y que un caballero de nombre Martín Ruiz, el que sería onceno maestre, se tituló como tal durante algún tiempo ${ }^{25}$; más adelante, entre 1234 y 1235 , se produjo una grave crisis que, animada por el propio rey Fernando III, era consecuencia del rechazo a lo que, en realidad, era legítimo intervencionismo del abad de Morimond en la designación del prior calatravo ${ }^{26}$; y finalmente, en 1236, un grupo de freires clérigos y caballeros, entre ellos nuevamente el aspirante al maestrazgo Martín Ruiz, elevaron quejas al Papa contra el maestre - con toda probabilidad Fernando Pérez - a quien acusaban de irregularidad e intrusión ${ }^{27}$. ¿Cabría ante semejante panorama que alguno de los dos maestres del período, Gonzalo Ibáñez y Fernando Pérez, hubiese sido apartado de su dignidad o se hubiera visto obligado a renunciar a ella?

Martín Ruiz gobernó la orden únicamente dos años y no tenemos prueba alguna que permita afirmar que su finalización no coincidió con su fallecimiento. No es el caso del duocécimo maestre, Gómez Manrique, cuya elección en 1240 fue causa de escisión en el seno de la orden y origen de

\footnotetext{
${ }^{24}$ J.F. O'Callaghan, Don Fernán Pérez, un maestre desconocido de la Orden de Calatrava, 1234-1235, en "Hispania», 43 (1983), pp. 433-439.

${ }^{25}$ RaDES, Chronica de Calatraua, fol. $34 \mathrm{v}$.

${ }^{26} \mathrm{O}$ 'Callaghan, The Affiliation, pp. 52-53.

${ }^{27}$ ID. . Don Fernán Pérez, pp. 435-436.
} 
una tensa y profunda crisis de importantes consecuencias. De resultas de ella Gómez Manrique, presionado por el propio rey, abandonó el maestrazgo en 1243, sucediéndole el candidato regio Fernando Ordóñez, decimotercer maestre de la orden ${ }^{28}$, el cual, aunque no contamos más que con indicios para ello, sospechamos que corrió la misma suerte que su antecesor: la voluntad real, la del nuevo monarca Alfonso $X$, pudo poner fin a su gobierno en 1254 para situar al frente de la orden al decimocuarto maestre, Pedro Ibáñez, a quien el rey fue muy aficionado, aunque para ello hubiera de abandonar el maestrazgo de Alcántara del que había sido titular durante .20 años ${ }^{29}$.

\footnotetext{
${ }^{28} \mathrm{El}$ relato de Rades sobre la crisis originada a partir de la elección de Gómez Manrique es muy elocuente. El capítulo quedó muy dividido en la sesión electoral, y aunque Gómez Manrique obtuvo la mayoría de los votos, muchos caualleros y clerigos de la Orden dieron su voto al comendador mayor, Fernando Ordóñez, muy priuado del rey. La elección capitular fue confirmada nada menos que por el cardenal Juan, legado de la Sede Apostólica, pero la "minoría mayoritaria" no aceptó el resultado, cuestionó la confirmación y, lo que era más grave, decidió no prestar obediencia al nuevo maestre. La tensa situación no duró mucho: a instancia del rey don Fernando, por quitar la scisma que auia en la Orden, renunció a la dignidad, siendo naturalmente elegido en concordia, ahora sí, el comendador mayor. El grave precedente intentó ser suavizado mediante un acuerdo que sustraía al maestre dimisionario, apartado a Tierra de Campos, de la jurisdicción del nuevo electo, quedando inmediatamente sujeto a la Sede Apostólica con título de comendador mayor (RADES, Chronica de Calatraua, fols. 40 v y 41 r).

${ }^{29}$ RADES, Chronica de Alcantara, fol. $10 \mathrm{v}$, y Chronica de Calatraua, fol. $44 \mathrm{r}$.

Aunque Rades y el casi siempre bien informado Torres y Tapia no dudan de la muerte en 1254 del maestre Fernando Ordóñez (A. DE TORRES Y TAPIA, Crónica de la Orden de Alcántara, Madrid, 1763, I, p. 335), nos inclinamos a proponer la hipótesis de su renuncia forzada a partir, sobre todo, del testimonio que nos ha llegado a través de las actas capitulares de Cîteaux correspondientes a 1254. Aquel año en el capítulo general de la orden, habitualmente celebrado el 14 de septiembre, se estudió una petición del rey de Castilla para que se procediera a la unificación y sometimiento de las órdenes de Calatrava y Alcántara, en lo referente a asuntos temporales, al convento madre de Calatrava. El capítulo general, no queriendo pronunciarse, comisionó a los abades de Bujedo y Valbuena para que personalmente indagasen sobre la viabilidad de la propuesta y conociesen la voluntad al respecto de las duae filiae domus Calatraviae (J.M. CANIVEZ, Statuta Capitulorum Generalium Ordinis Cisterciensis ab anno 1116 ad annum 1786, II (ab anno 1221 ad annum 1261) Louvain, 1934, p. 406). Es evidente que la propuesta real - extraordinariamente significativa, según veremos más adelante - no llegaría a ser atendida, pero interesa destacar que el texto capitular, al referirse a las circunstancias que posibilitaban la solicitud castellana, alude a la doble vacante maestral que en ese momento se producía con la expresión remotis magistris. Ciertamente fue removido Pedro Ibáñez que hubo de abandonar la orden de Alcántara para hacerse cargo de la de Calatrava, pero es también posible que el titular calatravo fuera forzado a renunciar —como sugiere la expresión- para facilitar la operación de recambio.

Desde luego, contamos con algunos indicios que podrían apoyar la hipótesis. Sorprende, por ejemplo, que en los listados de confirmantes de los primeros privilegios rodados alfonsinos figuren, prácticamente sin solución de continuidad, los maestres Fernando Ordóñez y Pedro Ibáñez al frente de la orden de Calatrava: el primero lo hace en uno de 16 de abril de 1254, apareciendo el segundo apenas cuatro días después (M. GONZÁLEZ JIMÉNEZ (ed.), Diplomatario
} 
Si la elección de Pelayo Pérez Correa supone el inicio de una nueva etapa en el desarrollo institucional de la orden de Santiago, algo semejante cabe decir en lo que se refiere a la de Calatrava con el comienzo del maestrazgo de Pedro Ibáñez, decimocuarto titular de la orden. A partir de ese momento, el fallecimiento de los maestres pone fin casi invariablemente a sus mandatos. Así ocurrirá con los restantes maestres del siglo XIII: el propio Pedro Ibáñez en $1267^{30}$, y sus sucesores el decimoquinto titular, Juan González, en 1284, y el decimosexto Ruy Pérez Ponce, en $1296^{31}$.

Andaluz de Alfonso X, Sevilla. 1991, docs. 128 y 129, pp. 131 y 132); el hecho nos muestra, cuanto menos, un significativo automatismo, máxime si tenemos en cuenta que, según Torres y Tapia, debió producirse un prolongado paréntesis en el que tendrían lugar las correspondientes consultas con la abadía de Morimond, a la que correspondía confirmar los relevos (TORRES, Crónica, I, p. 341). Por otra parte, una bula papal fechada en los primeros días de enero de 1256, dirigida al abad de Morimond y al maestre y orden de Calatrava, venía a recordar oportunamente el respeto de que debía ser objeto la reglamentación existente en materia de designación y destitución de maestres calatravos y que no era otra que la concerniente a los abades cistercienses. Publ. Bulario de Calatrava, p. 109, e I. Rodríguez DE LAMA, La documentación pontificia de Alejandro IV (1254-1261), Roma, 1976, doc. 143, pp. 155-156.

Pero, si es que realmente fue así, icuáles podían ser los motivos de Alfonso $X$ para provocar la renuncia del maestre Fernando Ordónez, un fiel servidor del gobierno de Fernando III a quien debía su promoción a la más encumbrada responsabilidad de la orden? Por lo pronto sabemos que Fernando Ordónez, que estuvo siempre al lado de san Fernando, actuó de custodio de los títulos de propiedad que Fernando III quiso otorgar a su hijo el infante don Enrique sobre ciertas posesiones fronterizas con Granada de próxima conquista, concretamente un estratégico señorío integrado por Jerez, Lebrija, Arcos y Medina. Sabemos también que Alfonso $\mathrm{X}$ disconforme con las medidas de su padre, exigió a los calatravos, ya siendo rey, la entrega de dichos títulos para proceder a su invalidación (GONZÁLEZ, Diplomatario, doc. 15. p. 14). El hecho provocó el disgusto del infante y probablemente también del maestre con quien gozaba de muy buena relación: no sólo le había hecho depositario de sus títulos de propiedad sino que le favoreció con donaciones en Morón y en el término de Arcos (R. SÁnchez Saus, Las órdenes militares en la provincia de Cádiz, en "Cádiz en el siglo XIII", Cádiz, 1983, pp. 5051). La oposición hacia Alfonso $X$ del infante don Enrique, rodeado de los íntimos colaboradores de su padre, entre ellos Diego López de Haro, acabaría en ruptura en los últimos meses de 1254; se trataba del primer enfrentamiento serio de un significativo sector de la nobleza contra el monarca, un enfrentamiento que de algún modo podía legitimarse en la rupturista estrategia de concesiones de que hacía gala frente a los usos del reinado anterior. No se puede demostrar fehacientemente, pero no tendría nada de particular que el maestre Fernando Ordóñez hubiera llegado a estar implicado en la revuelta antialfonsona; lo que, en cualquier caso, no resulta fácil cuestionar es el interés que seguramente mostró el nuevo monarca castellano en prescindir de tan incómodo servidor de su padre y su inquebrantable voluntad de poner al frente de la institución a un inequívoco y fiel colaborador personal, máxime cuando desde un principio Alfonso $X$ apostó firmemente por la orden de Calatrava para la que, además, tenía proyectos de engrandecimiento a costa de la de Alcántara.

${ }^{30}$ Pedro Ibáñez, según Rades, adoptó un coadjutor que se titulaba maestre cuando dos años antes de morir se vio prácticamente incapacitado para regir la orden. Este maestre-coadjutor sería el que acabaría sucediéndole, pero sin embargo Pedro Ibáñez nunca llegó a renunciar (RADES, Chronica de Calatraua, fol. 45 r).

${ }^{31}$ Parece que murió de resultas de las heridas recibidas en enfrentamiento con los musulmanes (RADES, Chronica de Calarraua, fol. 46). 
Caso aparte lo constituirá el decimoséptimo maestre calatravo, García López de Padilla, que, tras largo gobierno y ya avanzada la primera mitad del siglo XIV, hubo de hacer frente a una importante crisis que le desplazó del maestrazgo $0^{32}$.

\subsection{Orden de Alcántara}

Los datos relativos a los maestres alcantarinos resultan algo menos significativos por la nebulosa que preside su trayectoria en la primera mitad del siglo XIII, pero todo apunta hacia una realidad muy distinta a lo que hemos visto para santiaguistas y, en menor medida, para calatravos, cuyos mandatos maestrales eran frecuentemente interrumpidos por renuncias o ceses. Sanjulianistas y alcantarinos desconocen, en principio, esa dinámica. No tenemos testimonios evidentes de ninguna renuncia maestral, siendo los mandatos de sus titulares temporalmente duraderos y, por consiguiente, aparentemente estables. Repasemos los datos de que disponemos.

Nada sabemos acerca de las circunstancias de finalización del gobierno del primer maestre - prior inicialmente- don Gómez, que debió producirse el año $1200^{33}$, ni tampoco del segundo maestre Benito Suárez que gobernó la orden hasta por lo menos $1216^{34}$. Con toda seguridad en 1218 la rige ya su tercer maestre, Nuño Fernández, aunque lo hizo por muy poco tiempo: los cronistas de la orden están de acuerdo en señalar el año 1219 como la fecha de su fallecimiento ${ }^{35}$. El cuarto maestre, García Sánchez, murió a comienzos de 1227, aunque es discutible que lo hiciera en el cerco de Montánchez como quiere Rades ${ }^{36}$, y también parece que fue el fin natural de la vida el que puso término, en 1234, al gobierno del quinto maestre alcantarino Arias Pérez ${ }^{37}$. Muy otras circunstancias son las que determinaron el final de la gestión del sexto maestre Pedro Ibáñez, que tras

\footnotetext{
${ }^{32}$ S. DE Moxó, Relaciones entre la Corona y las Órdenes militares en el reinado de Alfonso $X I$, en «VII Centenario del Infante D. Fernando de la Cerda, 1275-1975», Madrid, 1976, p. 129.

${ }^{33}$ Rades, Chronica de Alcantara, fol. 3 v; TORRES, Crónica, I, p. 121.

${ }^{34}$ TORRES, Crónica, I, p. 171. Torres rebate la fecha de 1208 sugerida por Rades como el año del fallecimiento del maestre (RADES, Chronica de Alcantara, fol. $4 \mathrm{v}$ ).

${ }^{35}$ RAdes, Chronica de Alcantara, fol. 7 r; TORRes, Crónica, I, p. 211.

${ }^{36}$ RADES, Chronica de Alcantara, fol. 8 r; TORRES, Crónica, I, p. 238.

${ }^{37}$ RAdES, Chronica de Alcantara, fol. 9; TORRES, Crónica, I, p. 261.
} 
largo gobierno de 20 años pasó en 1254 a administrar, por voluntad regia, la orden de Calatrava.

Esta última sería la gran excepción del siglo XIII. Los maestres de la segunda mitad de la centuria hacen gala de gobiernos vitalicios relativamente extensos. Lo es, desde luego, el del séptimo maestre García Fernández, fallecido en 1284 tras 30 años de gestión, y lo son, aunque en mucha menor medida, los del octavo maestre, Fernando Páez, muerto en 1292, el noveno titular, Fernando Pérez Gallego, fallecido en 1298, y el décimo, Gonzalo Pérez, cuyo gobierno se extiende a los 16 primeros años del siglo XIV ${ }^{38}$.

\section{Claves explicativas}

Después del repaso realizado, los datos no pueden ser más elocuentes. Si exceptuamos a los respectivos fundadores, sabemos que el 75 por ciento de los maestres santiaguistas de la primera mitad del siglo XIII $\longrightarrow 9$ frente a 3- acabaron sus mandatos mediante renuncia, y algo más del 50 por ciento de los calatravos - 6 frente a 5 - hicieron lo propio, constituyendo únicamente excepción los maestres alcantarinos entre los que sólo uno frente a cuatro podemos afirmar con certeza que abandonó sus responsabilidades de gobierno antes de su fallecimiento.

$\mathrm{Si}$ por otra parte comparamos estos datos con el abrumador porcentaje de maestres que, a partir de mediados del siglo XIII, fallecieron en el cargo, es razonable pensar que un cambio se opera en la evolución institucional de la dignidad maestral precisamente en ese momento. Para empezar a desentrañarlo convendría contestar a una primera pregunta: ¿cuáles son las razones que inducen a los maestres de la primera hora a renunciar, casi sistemáticamente entre los santiaguistas y de manera significativa aunque mucho menos abrumadora entre los calatravos?

Los cronistas más cercanos a ellos, los santiaguistas Orozco y Parra en relación a los maestres de su orden, aducen invariablemente una única motivación: la humildad; expresiones tales como el deseo de "antes servir i obedesçer su orden, como buen religioso, que ser servido y obedesçido",

\footnotetext{
${ }^{38}$ Rades y Torres difieren en las fechas de fallecimiento de estos dos últimos maestres Preferimos la versión más documentada de Torres y Tapia (TORRES, Crónica, I, pp. 448 y 504).
} 
o "dexolo no se fallando digno de tan gran tarea"39 nos muestran una estereotipada explicación, por sistemática, poco creíble. Un cronista moderno como Rades apunta, en cambio, en otra dirección: la esencial función militar de las órdenes hacía que los maestres renunciasen cuando la enfermedad, la vejez o las heridas recibidas en combate les convertían en inhábiles para la guerra ${ }^{40}$ Razones por tanto inherentes al espíritu religioso o a la vocación militar de los freires estarían, pues, en la base explicativa de un reiterado fenómeno de renuncia, al menos desde la interesada óptica justificadora del «oficialismo» cronístico ${ }^{41}$.

No dudamos que esos factores fueran en algunos casos determinantes, pero nos resistimos a hacer de ellos explicación excluyente del fenómeno de generalizada renuncia, desde el momento en que ni el espíritu religioso ni mucho menos la vocación militar fueron ajenos a los maestres, frecuentemente vitalicios, que se hicieron cargo de las responsabilidades de gobierno a partir de los años 40 ó 50 del siglo XIII. Creemos que es preciso acudir a otra explicación integradora que, siendo global, permita encajar sin mayores dificultades los distintos niveles de intensidad con que se manifiesta, según las diferentes órdenes, esta generalizada tendencia a la dimisión. Y esa explicación no puede ser otra que la inconsistencia y debilidad de la propia institución maestral hasta que una serie de factores objetivos permitan consolidarla a partir de mediados del siglo XIII. La dimisión voluntaria o la renuncia forzada - muy difícil de distinguir con los datos de que disponemos- serían, pues, la manifestación de un recelo generalizado nacido en las propias órdenes que impediría la consolidación de eficaces poderes monárquicos al frente de ellas. El espíritu marcadamente aristocrático del origen mismo de las órdenes y su propio carácter de corporación o

\footnotetext{
${ }^{39}$ OrOzCO-PARRA, Historia de la Orden, pp. 358 y 364 . Las expresiones reproducidas corresponden concretamente a las renuncias del segundo y del onceno maestre, Fernando Díaz y Fernando Pérez Chacín, respectivamente.

${ }^{40}$ RADES, Chronica de Sanctiago, fol. 22 v. A esas causas genéricas que el cronista concreta en algunos maestres calatravos como Fernando Escaza, Nuño Pérez Quiñones o Rodrigo Díaz (Chronica de Calatraua, fols. 17 v, 21 y 30 v), añade también, aunque según interpretaciones discutibles, la presión regia como causa de dimisión: lo sugiere en los casos de los maestres santiaguistas Fernando Díaz y Martín Peláez Barragán, por ejemplo (Chronica de Sanctiago, fols. $16 \mathrm{v}-17 \mathrm{r}$ y 26 )

${ }^{41}$ Lomax recoge, en lo que se refiere a Santiago, los factores tradicionalmente admitidos como causas excluyentes: enfermedad, edad, vocación religiosa estrictamente clerical e incluso incapacidad como fue el caso de Fernando Pérez Chacín (Lomax, La Orden de Santiago, p. $55)$.
} 
comunidad religiosa, resultaban esencialmente incompatibles con unos maestres de perfil jerárquico incontrastable cuya primera manifestación de poder consistiría en la consecución de gobiernos lo suficientemente estables y duraderos como para permitir imponer pautas de gestión personalista.

En efecto, no hace falta insistir en esas dos notas definitorias de las órdenes militares - carácter aristocrático y dimensión comunitaria- que explican desde ellas mismas el rechazo a fórmulas de poder sobreimpuesto marcadamente diferenciadas. En cambio, sí puede resultar ilustrativo establecer ciertas matizaciones en lo que se refiere a su distinto grado de aplicación en cada una de las órdenes. No es igualmente intensa, por ejemplo, la proyección aristocrático-nobiliaria en el caso de la secularizante fórmula santiaguista que en el modelo monástico calatravo-alcantarino. Del mismo modo, no es idéntica la institucionalizada expresión comunitaria en este último modelo, pronto mediatizado por el verticalismo cisterciense, que entre los santiaguistas, sujetos más débilmente a estructuras jerárquicoreligiosas exteriores a la propia orden.

Todo ello nos ayuda a explicar las diferencias que hemos percibido a la hora de constatar una mayor o menor frecuencia de renuncias maestrales. La máxima expresión de las mismas la hallamos en la orden de Santiago, la más aparentemente aristocrática, es decir, aquélla cuya estructura formal originaria es más deudora de la secularizante, oligárquica y al mismo tiempo igualitaria noción de cofradía caballeresca ${ }^{42}$, y en la que, además, se desconocen mecanismos exteriores que podrían apuntalar los gobiernos maestrales en aras de una mayor integración en estructuras jerárquicas amparadoras. Este último es el caso de las órdenes de Calatrava y Alcántara. Se trata ciertamente de instituciones también nobiliarias en su origen, aunque atemperadas por su propia esencia monástica, y en las que la realidad comunitaria y horizontal, muy fuerte en sus orígenes benedicti-

\footnotetext{
${ }^{42}$ Es de sobra conocido el texto contenido en la bula fundacional santiaguista de 1175 cuya redacción se atribuye al cardenal Alberto de Morra, y en el que se verifica una adaptación a la realidad peninsular de la justificación bernardiana de la caballería. En dicho texto se subraya el carácter caballeresco y nobiliario de los primeros santiaguistas, antiguos equites diaboli convertidos en fieles de Jesucristo (Bulario de Santiago, pp. 1-2).

Los cronistas Orozco y Parra, por su parte, se encargan de subrayar más esta idea de originaria cofradía de nobles, al atribuir sistemáticamente hasta el octavo maestre, dimitido ya en 1217, su condición de pertenencia al estado de los dichos primeros treze cavalleros ynventores, con lo que de manera indirecta se recalcaba su condición de deudores de una primitiva y oligárquica idea nobiliaria de fundación, por lo demás muy acorde con el aristocratizante espíritu de finales del siglo XV en que escriben (OROZCO-PARRA, Historia de la Orden, pp. 359-361).
} 
nos, se verticaliza en aras de una cada vez mayor integración en los esquemas cistercienses.

En este sentido es muy significativo que, frente al inestable cuadro de renuncias que nos muestran los santiaguistas, las órdenes de Calatrava y Alcántara se manifiestan más estables. Ahora bien, por la misma razón, debe ser igualmente anotado que las renuncias de maestres calatravos se concentran en los primeros tiempos de andadura de la institución, hasta 1210 aproximadamente, que es cuando la incorporación a las estructuras cistercienses se ha consumado definitivamente. Y por último, es también reseñable que sea la orden de Alcántara, la más tardía en su nacimiento y desarrollo inicial y, por tanto y en comparación, la más prematuramente integrada en el esquema cisterciense -en especial desde que en 1218 acaba por regularizarse en plenitud su dependencia calatrava-, la que nos aparezca como más estable en lo referente a sucesiones maestrales.

Estas afirmaciones que, por otra parte, no constituyen más que una hipótesis de trabajo sobre la que convendrá profundizar, pueden ser ilustradas con datos concretos que apuntan en una doble y contradictoria dirección: la tendencia de la comunidad capitular de los freires de cualquiera de las tres órdenes a frenar la inercia hacia el protagonismo de sus respectivos maestres, y la irrefrenable inclinación de éstos a crear fórmulas que independizasen su poder, individualizándolo y garantizando, de este modo, su consolidación y permanencia.

Los datos a los que hacemos referencia son en muchos casos meros indicios, pero creemos que suficientemente significativos. En efecto, indicios de esta doble y contradictoria tendencia encontramos en los conflictos surgidos entre maestres y freires caballeros a la hora de repartir los beneficios derivados de campañas contra los musulmanes, o en las luchas por el control de rentas diezmales que se entablan entre maestres y freires clérigos. Ejemplos del primer tipo de enfrentamientos — que suponemos debieron ser más frecuentes de lo que nos permiten deducir las fuentes- los hallamos, desde finales del siglo XII, entre los calatravos ${ }^{43}$, y muestras del

\footnotetext{
${ }^{43}$ Pensamos que la primera renuncia de Martín Pérez de Siones, en 1182 , pudo deberse a la incontenible tensión nacida años antes como consecuencia de los sucesos derivados de la reocupación del castillo de Almodóvar, ocurrida poco después de su acceso al maestrazgo. Entre las razones del descontento de los caballeros hacia su maestre en aquella ocasión, Rades destaca que no repartio el despojo a su gusto. Ello llegaría a provocar un cisma, en buena medida abortado por los freires clérigos (RADES, Chronica de Calatraua, fols. 17 v-18 r). Tras los datos aportados por Rades - muy extenso y colorista en su relato- descubrimos una voluntad
} 
segundo, durante la primera mitad del siglo XIII, entre los santiaguistas ${ }^{44}$. Unos y otros son manifestación del deseo maestral de parcelar en su beneficio la «mesa común», y de las resistencias de la orden a perder la gestión indivisa de dicha mesa.

El recelo de las propias órdenes hacia el encumbramiento de sus titulares no se detenía en la, en ocasiones, forzada renuncia maestral. En 1199 el papa Inocencio III se veía obligado a recordar, sobre previos pronunciamientos capitulares de los cistercienses, que ningún maestre calatravo dimisionario o cesado tomara para sí bienes comunes sino sólamente aquéllo que el convento le asignara ${ }^{45}$. El convento, la comunidad, se convertía en el único dispensador de medios gestionables por un maestre, antes y después de su renuncia. A veces esa renuncia se compraba a un elevado precio, pero era preferible ceder vitaliciamente bienes y rentas a un dimisionario que permitir a un maestre activo demasiada libertad de movimientos ${ }^{46}$.

\footnotetext{
maestral de crearse medios propios que le permitieran, al margen de la comunidad, una cierta capacidad de maniobra. Así creemos debe interpretarse el desacuerdo sobre reparto de botín, un desacuerdo que llevaría a los «pares» de la orden a exigir, a través de un maestre intruso, una indemnizadora compensación. Resulta significativo que el sector clerical apoyara al maestre legítimo. Ellos eran de algún modo los garantes de un orden jerárquico foráneo que exigía estabilidad. El maestre se mantuvo en su dignidad, pero acabó dimitiendo años después.

${ }^{44}$ Los conflictos por el control de diezmos son específicos de la orden de Santiago. Su estructura institucional cerrada sobre sí misma hacía que los diezmos producidos por los freires caballeros y sus bienes debieran ser percibidos por los clérigos de la orden. Un sistema de estas características daba origen a innumerables conflictos, y especialmente violento fue el que durante más de 40 años -entre las décadas de los 20 y de los 60 del siglo XIII- sostuvieron maestres y priores santiaguistas. M. RIVERA GARRETAS, La encomienda, el priorato y la villa de Uclés en la Edad Media (1174-1310). Formación de un señorío de la Orden de Santiago, Madrid-Barcelona, 1985, pp. 214-221; RADES, Chronica de Sanctiago, fol. 27.

${ }^{45}$ Bulario de Calatrava, p. 35; D. MANSILlA, La documentación pontificia hasta Inocencio III (965-1216), Roma, 1955, p. 209, doc. 195.

${ }^{46}$ En ocasiones, los maestres dimisionarios conseguían acomodados retiros y cierto status de privilegio conservando títulos y gozando de algunas rentas. El segundo maestre santiaguista, por ejemplo, recibió el monasterio realengo de San Audito con exención jurisdiccional respecto al nuevo maestre (RADES, Chronica de Sanctiago, fol. 17 r). Mucho más adelante, en 1243, el duodécimo maestre calatravo se veía obligado a dimitir, pero conservó, entre otras cosas, el título de comendador mayor (vid. supra n. 28).
} 


\section{LOS PROCESOS DE TRANSFORMACIÓN DE LA SEGUNDA MITAD DEL SIGLO XIII}

Pero todo ello inevitablemente se traducía en una debilitada imagen de la figura del maestre ${ }^{47}$, que sólo empezaría a ser superada a partir del año 1260 aproximadamente. En torno a aquella fecha y en los años inmediatamente posteriores, las dos más importantes órdenes militares, Calatrava y Santiago - muy probablemente también, aunque en menor proporción, Alcántara-, sufren en su seno procesos críticos muy desestabilizadores, auténticas rebeliones internas que pusieron en grave peligro la gestión al frente de ellas de sus respectivos maestres. La novedad de ambos fenómenos no radica en el hecho en sí de un movimiento interno tendente a doblegar al maestre e incluso a derrocarlo llegado el caso. Es posible que algunas de las renuncias del período anterior fueran precedidas de turbulencias de las que, en la mayoría de los casos, no nos han llegado testimonios. Lo que representa, en cambio, una novedad es el grado de intensidad de unos movimientos que el oficialismo cronístico no ha podido silenciar; pero, sobre todo, es nuevo el hecho de que dichos movimientos de características tan violentas no acabaran en renuncia maestral: de un modo u otro pudieron ser remontados por los respectivos maestres. Sin duda, el calatravo Pedro Ibáñez y el santiaguista Pelayo Pérez Correa —en menor medida el alcantarino García Fernández- inauguran, así, una nueva fase en la trayectoria institucional de sus respectivas órdenes, una fase de fortalecimiento de la propia dignidad maestral.

Veamos brevemente en qué consistieron las aludidas revueltas, y cuáles fueron los mecanismos que permitieron a los maestres superarlas. En ellos habremos de ver las claves de su consolidación.

\footnotetext{
${ }^{47}$ En otro trabajo hemos insistido en esta debilidad inicial de la imagen maestral: C. DE Ayala Martínez, Maestres y maestrazgos en la Corona de Castilla (siglos XII-XV), en "Las Órdenes Militares en la Península Ibérica». Congreso Internacional celebrado en Ciudad Real en mayo de 1996 (en prensa).
} 


\section{El conflictivo gobierno de Pedro Ibáñez, maestre de} Calatrava (1254-1267)

\subsection{Crisis e inestabilidad en la orden}

El gobierno del maestre Pedro Ibáñez de Calatrava (1254-1267) cuenta con tres conflictivos hitos que lo jalonan y, en buena medida, nos ayudan a comprenderlo. El primero tiene lugar en vísperas de su formal elección, cuando en los primeros meses de 1254 Alfonso X solicitaba del capítulo general de Cîteaux la unificación de las órdenes de Alcántara y Calatrava, bajo el control, de esta última para cuyo gobierno ya contaba con un candidato idóneo: Pedro Ibáñez, dimisionario maestre de Alcántara ${ }^{48}$. La segunda de las referencias conflictivas alude al descontento y escándalo que produjo en la abadía de Morimond y en el capítulo cisterciense de 1260 la virtual entrega de las fortalezas de la orden que Pedro Ibáñez, ya desde el maestrazgo, había verificado a favor del rey Alfonso X de Castilla ${ }^{49}$. Finalmente, el tercer elemento conflictivo fue la decisión real de trasladar la sede central de la orden desde Calatrava hasta la villa fortificada y fronteriza de Osuna en diciembre de $1264^{50}$.

Los tres acontecimientos tienen un único denominador común: el deseo del rey de someter a su voluntad la orden de Calatrava con la activa colaboración de su maestre. Si el proyecto real se hubiera finalmente impuesto, nos encontraríamos con una única gran orden cisterciense regida por un íntimo colaborador del rey a cuya disposición entregaba su inmenso y decisivo patrimonio castral y cuya orientación militar y fronteriza, reforzada con el traslado del convento central a Osuna, la apartaba de inevitables tentaciones de presión señorial, nacidas de una excesiva concentración fundiaria y jurisdiccional en las tierras manchegas del Campo

\footnotetext{
${ }^{48}$ Vid. supra n. 29.

${ }^{49}$ "Cum de facto Calatraviae clamor devenerit ad Capitulum generale quod Magister eiusdem loci castra ad eumdem locum pertinentia alienaverit quodammodo regi Castellae, de eisdem castris homagium faciendo, et abbas Morimundi, pater Calatraviae, hoc audito, in continent hanc alienationem revocaverit auctoritate paterna, et insuper excommunicaverit omnes qui huic alienationi de cetero assensum praebuerint, dictam revocationem et excommunicationem approbat et confirmat dictum Capitulum generale. De eiectione vero fratrum, et de aliis ad hanc causam pertinentibus committitur abbati Morimundi, quod per se vel per alios diligenter inquirat et corrigat, et quae forte corrigere non potuerit, anno sequenti renuntiet Capitulo generali" (CANIVEZ, Statuta, II, p. 468).

${ }^{50}$ GonZÁlez, Diplomatario, doc. 297 , pp. $323-324$, y doc. 299 , p. 325
} 
de Calatrava ${ }^{51}$. El hecho hay que situarlo en la perspectiva «regalista» de Alfonso $\mathrm{X}$, el monarca responsable de un primer diseño de monarquía soberana para Castilla, una monarquía de vocación, por tanto, jurisdiccionalmente excluyente ${ }^{52}$.

La elección de Calatrava para este ensayo intervencionista que sin duda serviría de modelo aplicable en su momento a Santiago ${ }^{53}$, puede obedecer a razones puramente políticas de carácter coyuntural. Es cierto que, en teoría, la estructura reglar de la orden de Santiago la convierte en institución más mediatizable políticamente hablando que lo eran las órdenes de obediencia cisterciense dependientes de instancias monástico-capitulares de carácter extrapeninsular ${ }^{54}$, pero no es menos cierto que el inicio del reinado de Alfonso X, que es cuando se intenta poner en práctica el plan de control de las órdenes militares a través de Calatrava, es un momento de

\footnotetext{
${ }^{51}$ Es inevitable llamar la atención en el correlato existente entre la decisión real del traslado de la sede conventual calatrava en 1264 y las primeras disposiciones en orden a crear un núcleo realengo de importancia evidente - Villa Real - en el corazón mismo del dominio calatravo, primeras disposiciones que se adoptan entre 1255 y 1262. Vid. L.R. VILLEGAS, Una gran villa $e$ bona. Apostillas sobre la fundación de Ciudad Real, en "Alfonso X y Ciudad Real. Conferencias pronunciadas con motivo del VII Centenario de la muerte del Rey Sabio (12841984)", Ayuntamiento de Ciudad Real, 1986, en especial pp. 21-22; F. RuIz GómEZ, La cartapuebla de Ciudad Real (1255). Comentario histórico-jurídico, ibid., en especial p. 43.

${ }^{52}$ Pocos testimonios tan inequívocos de este claro objetivo de gobierno como el que nos ofrece una decisión real de 1254 por la que, en materia de administración de justicia, la jurisdicción propia del realengo era extendida a cuantas tierras de señorío tuvieran su origen en donaciones regias, lo cual naturalmente le daba un extraordinario margen de actuación judicial en extensos dominios de abadengos y órdenes militares cuyo origen hay que buscarlo en la dadivosa actitud que tradicionalmente venía mostrando la monarquía hacia las instituciones religiosas. La decisión real aludida se produjo en el contexto del contencioso que por la posesión de Ronda enfrentaba a las órdenes militares del Temple y de Alcántara. El 18 de marzo de aquel año, el Rey Sabio, ante las quejas del maestre del Temple, ordenaba al deán y maestrescuela de Zamora y al arcediano de Toro, subdelegados pontificios en dicho contencioso, que se inhibieran del mismo, puesto que, según aducía el maestre del Temple, Ronda le había sido concedida a su orden por donadío real, y el monarca entendía que ningún pleito relativo a realengo o a donadío real debía ser sentenciado por tribunal eclesiástico sino únicamente real Publ. TORRES, Crónica de Alcántara, I, p. 334.

${ }^{53} Y$ también a Alcántara, mucho después de que se mostrara inviable la integración promovida en 1254. Pensemos, por ejemplo, en la concesión real de los castillos de Morón y Cote verificada por Alfonso X en 1279: en el primero de ellos, rebautizado como Buenaventura se establecería el convento mayor de la orden (GonZÁLEZ, Diplomatario, pp. 478-480, doc. 453). La orden de Alcántara era, sin duda, la menos poderosa, pero presentaba también características de temible coherencia en tierras extremeñas. El paralelismo, por otra parte, entre Morón y Osuna desde un punto de vista estratégico y funcional resulta evidente. Vid. C. DE Ayala MARTínez, La monarquía y las órdenes militares durante el reinado de Alfonso $X$, en «Hispania», LI (1991), p. 437.

${ }^{54} \mathrm{C}$. DE AYALA, Maestres y maestrazgos en la Corona de Castilla (en prensa).
} 
muy tensas relaciones con Portugal por la cuestión del Algarve, un territorio en el que tantos intereses tenían -o presumiblemente habrían de obtenerlos santiaguistas, utilísimos instrumentos de sometimiento de la zona bajo la dirección del maestre portugués Pelayo Pérez Correa. Es probable, incluso, que el rey Alfonso III de Portugal estuviese diseñando entonces toda una estrategia de acercamiento al maestre santiaguista en el contexto de la «nacionalización» del territorio del Algarve ${ }^{55}$. La tensión luso-castellana no cedió hasta que en 1267 se firmó el tratado de Badajoz: había durado prácticamente lo que lo hizo el intento del Rey Sabio de someter a su autoridad la orden de Calatrava a través de su maestre. No hubiese sido ciertamente aconsejable, dadas las circunstancias políticas, proceder con los santiaguistas a tan arriesgada operación.

Sea por la razón que fuere, lo cierto es que el intento intervencionista de Alfonso X se centró en la orden de Calatrava al frente de la que, por muerte del anterior maestre -0 quizá por renuncia forzada $-{ }^{56}$, se hallaba un incuestionable y fidelísimo colaborador del rey. Sin embargo, ninguna de las iniciativas del monarca, sin duda entusiásticamente apoyadas por el maestre, encontró el apoyo del conjunto de la orden. El fracaso de las tres así parece demostrarlo ${ }^{57}$. Pero aparentemente que sólo en uno de los casos, la orden, o al menos un sector de ella, pudo responder con algo más que resistencia pasiva o actitudes testimoniales. Nos referimos al intento maestral de poner en manos del monarca las fortalezas de la institución. Parece que, a raíz de la escandalosa iniciativa, algunos freires - probablemente comendadores de núcleos fortificados resistentes a los planes del rey

\footnotetext{
${ }^{55}$ J. MARQUES, Os castelos algarvios da Ordem de Santiago no reinado de D. Alfonso III, en «Relaçôes entre Portugal e Castela nos finais da Idade Média», 1994, en especial p. 131. No obstante, el autor subraya las reticencias que tuvo el rey portugués a la hora de consolidar la presencia en el Algarve de una orden cuyo convento central se hallaba en territorios del reino de Castilla.

${ }^{56}$ Vid. supra n. 29.

${ }^{57}$ Incluso en el tema del traslado del convento, el rey no pudo vencer la resistente inercia de la orden, y ello pese a las extraordinarias condiciones que le eran of recidas: de hecho, contraviniendo antiguos preceptos confirmados por el propio Alfonso $\mathrm{X}$, la orden, además del montazgo que le correspondía por todos sus dominios castellanos, cobraría uno más en Osuna (GONZÁlEZ, Diplomatario, doc. 299, p. 325). En la práctica, Osuna, convertida en encomienda mayor, nunca llegó a ser, sin embargo, sede del convento central. Sobre todas estas cuestiones resulta conveniente consultar el trabajo de L.R. Villegas Díaz: Presencia de la Orden de Calatrava en Osuna. Una aproximación, en J.J. IGLESIAS RODRÍGUEZ y M. GARCÍA FERNÁNDEZ (eds.), "Osuna entre los tiempos medievales y modernos (siglos XIII-XVIII)", Ayuntamiento de Osuna-Universidad de Sevilla, 1995, en especial pp. 39-44.
} 
y su maestre - fueron expulsados del reino. El texto de las actas capitulares de Cîteaux del año 1260 no sólo recoge la reacción del abad de Morimond y del capítulo ante la «enajenación" de fortalezas, sino que alude a una expulsión de freires - de eiectione fratrum - $\mathrm{y}$ a otros asuntos relacionados con aquella cuestión, y que debían ser sometidos a la consideración del abad de Morimond. Ciertamente por aquellas fechas es cuando debió producirse la expulsión del reino de algunos calatravos acusados de prestar auxilium, consilium et favorem a los enemigos del rey. El papa Urbano IV intercede por ellos en enero de 1263 facilitándonos los nombres de cuatro, uno de los cuales muy bien podría tratarse del comendador mayor de la orden ${ }^{58}$. De confirmarse este último dato podríamos estar ante un movimiento de cierta envergadura; el comendador mayor era la máxima autoridad de la orden tras el maestre y es muy probable que su designación estuviera desde muy temprano mediatizada por el capítulo, aunque hasta 1397 no tengamos constancia de que su elección dependiera de éste ${ }^{59}$. En cualquier caso, su implicación en el aludido destierro nos podría llevar a pensar que, frente a un maestre impuesto por el rey como era Pedro Ibáñez, su discrepante comendador mayor bien podía representar una corriente de opinión, por lo menos significativa, en el interior de la orden.

De todas formas, pocos testimonios más podemos aducir sobre un movimiento del que sospechamos pudiera tener más relevancia de lo que dejan traducir tan escasos datos. Sin embargo, también es cierto que no es difícil asociar otras noticias a la resistencia que pudo provocar entre comendadores y caballeros calatravos el intrusismo regio y la servil actitud del maestre hacia el mismo. Sabemos que algunos de ellos abandonaron la orden rompiendo compromisos de profesión y llevándose consigo bienes de las encomiendas. Una disposición papal de mayo de 1264 prohibía taxativamente a los freires fugitivos de la orden de Calatrava que profesasen en otra institución en tanto no hubieran satisfecho las caballerías, dinero u otros

\footnotetext{
${ }^{58} \mathrm{AHN}$, OOMM, Calatrava, carp. 444, doc. 57. Bulario de Calatrava, p. 121. Los nombres facilitados son los de Alfonso García, Gómez González, Martín López y Raynero. Atendiendo a las relaciones de dignidades que nos ofrece Rades, Gómez González era con toda probabilidad comendador mayor de la orden (de hecho, el cronista alude a otros dos comendadores mayores en el periodo de tiempo que duró el maestrazgo de Pedro Ibáñez), y es posible que Alfonso García pudiera ser identificado con el Alfonso García de Celada que se hallaba al frente de la encomienda de Zorita (RADES, Chronica de Calatraua, fol. 45 r).

${ }^{59}$ J. O'CALlaghan, The Affiliation of the Order of Calatrava, p. 8; ID., Las Definiciones de la Orden de Calatrava, 1383-1418, en «En la España Medieval», 19 (1996), pp. 102 y 114.
} 
bienes que se hubieran llevado a expensas de ella ${ }^{60}$. Debieron producirse también encarcelamientos: no tenemos la certeza de que exista relación directa con los acontecimientos desencadenados a raíz de 1260 , pero sabemos que en 1267 el papa Clemente IV exigía del rey la puesta en libertad de ciertos freires caballeros que se hallaban en prisión ${ }^{61}$.

Disponemos finalmente de otro dato significativo que, hipotéticamente, podría asociarse al descontento generalizado que traducen los hechos expuestos. La crónica de Rades afirma que en 1265 el maestre Pedro Ibáñez, "viéndose muy viejo, tomó por coadjutor del maestrazgo" al clavero Juan González, al que "consintió que también se llamasse maestre". Tal situación se prolongó todavía dos años, hasta que en 1267 fallecía Pedro Ibáñez ${ }^{62}$. El dato no deja de sorprender. Lo hace el hecho de que la consciente vejez del maestre titular no implicara una renuncia como tantas veces había sucedido, y lo hace también, sobre todo, la instauración de este inédito mecanismo de cooptación que, de hecho, convirtió el gobierno de la orden, al menos durante dos años, en una auténtica diarquía.

Creemos que la clave de tal situación hay que buscarla en lo que podría constituir una solución pactada, fruto de una lucha de intereses contradictorios: el firme apoyo de la monarquía a un leal servidor y la creciente oposición interna que, entre caballeros y comendadores, suscitó el gobierno de un maestre autoritario, más preocupado por los intereses de la corona que por los de su propia orden. Las diversas iniciativas de Pedro Ibáñez -o mejor su leal colaboración en las del rey- dejaron tras sí destierros de freires calatravos y probablemente también huídas y encarcelamientos. En estas circunstancias no es extraño que un clamor interno se alzase contra el maestre. Muy pronto ese clamor pudo adoptar la forma de un cuestionamiento de su irregular elección. En enero de 1256, Alejandro IV recordaba que los procedimientos de institución y destitución de un maestre calatravo debían ajustarse a lo que la normativa cisterciense prescribía para los abades de la orden ${ }^{63}$. La firme actitud del rey impediría que la oposición pudiera materializarse en algo más concreto, pero lo que

\footnotetext{
${ }^{60}$ Bulario de Calatrava, pp. 121-122.

${ }^{61} \mathrm{AHN}$, OOMM, Calatrava, carp. 444, doc. 62.

${ }^{62}$ RADES, Chronica de Calatraua, fol. $45 \mathrm{r}$.

${ }^{63}$ Bulario de Calatrava, p. 109. RODRIGUEZ DE LAMA, La documentación pontificia de Alejandro IV (1254-1261), Roma, 1976, doc. 143, pp. 155-156 (con fecha 3 de enero).
} 
probablemente no pudo impedir es que, arguyendo la vejez del maestre, el clavero de la orden fuera aupado por el capítulo a la más alta responsabilidad de la institución con el fin de fiscalizar la acción del maestre titular. Y es que si la iniciativa del nombramiento de coadjutor hubiera partido de Pedro Ibáñez, lo coherente es que hubiera estado acompañada de su propia renuncia y no de la irregular atribución del título de maestre para quien no había sido elegido como tal. No deja de ser significativo, por otra parte, que el maestre-coadjutor, confirmado en la dignidad tras el fallecimiento de Pedro Ibáñez, no se mostrara nunca especialmente leal al rey Alfonso X. No era, sin duda, su candidato, como tampoco lo fue seguramente del realista maestre anterior: su ascenso era más bien el resultado de una transacción que había garantizado la continuidad de su predecesor y que garantizaba ahora el mantenimiento de una pacífica sumisión de la orden hacia la corona.

\subsection{Causas y manifestaciones de la crisis: el nacimiento de la mesa maestral}

Ahora bien, podría resultar simplista atribuir la permanencia del maestre Pedro Ibáñez únicamente a la férrea voluntad del monarca, como sería conceder excesivo protagonismo a la corona, pensar que el descontento de la orden hacia su titular tenía su exclusivo origen en la servil dependencia de éste respecto al rey. Fueron, sin duda, argumentos de peso, pero por sí mismos es improbable que puedan explicar toda la realidad. En cualquier caso, parece que es el protagonismo que adquiere el maestre en el seno de la orden, con o sin el decidido apoyo de la monarquía —en este último caso estará, según veremos, el maestre santiaguista-, lo que fundamentalmente preocupa a la orden, y lo que, en último término, provoca el recelo del colectivo de freires respecto a un maestre que hasta hacía muy poco tiempo no había sido otra cosa que un primum inter pares. Ese protagonismo es el que permite a la emergente figura del maestre optar por el diseño de una personal estrategia de gestión que, en el caso de Pedro Ibáñez, es la del colaboracionismo radical con la corona al margen de la voluntad colegiada de los calatravos. Esa estrategia reportaba, sin duda, importantes beneficios en forma de concesiones reales, pero ignoraba no sólo la voluntad concreta de los freires sino, lo que es más grave, la tendencia de éstos a la cristalización de su privilegiado status, de todo punto incompatible con un arbitrario, personalista y uniformador centralismo maestral. Esa tendencia, que con todas las reservas podemos llamar señorializadora, es común a todas las 
instituciones religiosas a partir de mediados del siglo XIII ${ }^{64}$, y lo es, en definitiva, a una sociedad cuyos cuadros socialmente influyentes $-\mathrm{y}$ no olvidemos que los freires eran, en principio, hidalgos caballeros - cierran sus círculos oligárquicos de poder ante los primeros y precursores signos de las críticas transformaciones que se avecinaban.

La fuerza que permite al maestre sobreimponerse al conjunto de la orden provocando en ella el natural recelo, descansaba en algo más que en el coyuntural apoyo de la corona. De hecho, será preciso relacionarla con el nacimiento de la mesa maestral. Mientras los maestres no contaron con medios propios de gestión y dependían de una «mesa común», indivisa y, por tanto, de conflictiva utilización, su capacidad de maniobra era extraordinariamente limitada y sus expectativas de permanencia al frente de la institución dependían de su sumisa actitud hacia el capítulo. Tampoco por entonces -durante los 75 primeros años de existencia de las órdenes hispánicas- los reyes repararon demasiado en la figura del maestre, que muy significativamente eqmpieza a figurar como testigo confirmante de los más solemnes documentos. reales a partir del comienzo de la segunda mitad del siglo XIII ${ }^{65}$ Hasta entonces las distintas órdenes, de manera colectiva y oligárquiéa, 'gestionaban una institución señorial en la que el titular de la misma veía en la práctica constreñidas sus funciones a poco más que a las meramente representativas.

La situación cambia cuando el maestre decide -0 puedeindependizarse del colectivo gobernado y para ello diseña una poderosa imagen monárquica firmemente asentada sobre una realidad material autónoma: la mesa maestral. En el caso de Calatrava es muy probable que el proceso no sea disociable del apoyo de la corona, dado quién lo protagonizó inicialmente y con qué fin. Pero esto no fue así en todas las órdenes.

En cualquier caso, es muy poco lo que sabemos de la creación de la mesa maestral calatrava. Los distintos autøres que han aludido al tema asumen sin dificultad la fecha de 1280 que en su día, y basándose en unas notas del archivero y calatravo. Luis Salazar y Castro, apuntó Manuel Danvila en su conocido informe sobre el origen y características de la

${ }^{64} \mathrm{C}$. DE AYALA MARTÍNEZ, Órdenes militares hispánicas: reglas y expansión geográfica, en "Los monjes soldados. Los templarios y otras órdenes militares», Aguilar de Campoo, 1996, pp. 68-69.

${ }^{65}$ AyAla, Maestres y maestrazgos en la Corona de Castilla (en prensa). 
institución que nos ocupa ${ }^{66}$. En efecto, la fecha es razonable, pero estimamos que la constitución de la mesa maestral dependió de un proceso formativo, probablemente traumático o al menos altamente conflictivo, cuyos orígenes deben ser anteriores a esa fecha concreta. Si aceptásemos esta última sin más, nos situaríamos ante el fruto de una puntual decisión adoptada que, de haberse producido como tal, difícilmente no habría dejado huella documental. En este sentido, nos parece más oportuno asociar al conflictivo maestrazgo de Pedro Ibáñez y no al de su sucesor Juan González el momento en que podría comenzar a hablarse ya de mesa maestral calatrava, o al menos, de primeros intentos de imposición de la misma ${ }^{67}$.

Varios indicios podrían servirnos para apoyar esta última conjetura. Todos ellos se relacionan con la conflictiva trayectoria del gobierno maestral de Pedro Ibáñez, y es que muy probablemente en el recelo que dicho gobierno suscitó entre freires y comendadores se reprochaba algo más que entreguismo a la corona: su telón de fondo bien pudo ser el de la personalizada individualización de un conjunto de rentas y derechos que, desgajados de la mesa común y convertidos en mesa maestral ${ }^{68}$, sirvieran de operativa base de operaciones para llevar a cabo su gestión. Es muy significativo en este sentido -y éstos son los indicios a los que aludíamos- que las muestras de rechazo de los miembros de la orden hacia su maestre vayan acompañados de un cierto deseo privatizador que muy bien podría interpretarse como respuesta al unilateral intento de ruptura de la mesa común practicado por el maestre con el decidido apoyo de la monarquía. En el caso de las fortalezas la cuestión no resulta demasiado nítida, pero tras el rechazo de la puesta a disposición del rey de los castillos de la orden, se adivina una airada respuesta por parte de quienes habían hecho de ellas firmes baluartes

\footnotetext{
${ }^{66} \mathrm{M}$. DanVILA, Origen, naturaleza y extensión de los derechos de la mesa maestral de la Orden de Calatrava, en "Boletín de la Real Academia de la Historia». XII (1888), pp. 126-127. L.R. VILlEGAS Díaz, Las estructuras de poder de la Orden de Calatrava. Una propuesta de análisis, en «Historia, Instituciones, Documentos", 18 (1991), pp. 491 y 494. E. RoDRíGUEZPICAVEA MATILla, La formación del feudalismo en la meseta meridional castellana. Los señoríos de la Orden de Calatrava en los siglos XII-XIII, Madrid, 1994, p. 163.

${ }^{67} \mathrm{El}$ propio Danvila sugiere la posibilidad de que su constitución fuera anterior a 1280 : DANVILA, art. cit., p. 132.

${ }^{68} \mathrm{La}$ última mención expresa a la mesa común calatrava data de 1247 . El 17 de mayo de aquel año el papa Inocencio IV protegía los bienes a ella pertenecientes de cualquier imposición que, en forma de subsidio o colecta, se quisiera hacer recaer sobre ellos sine speciale mandato nostro. Bulario de Calatrava, p. 86; A. QUINTANA PRIETO, La documentación pontificia de Inocencio IV (1243-1254), Roma, 1987, vol. I. doc. 409, p. 404.
} 
de poder, expresión de una incontenible marea señorializadora que a todos afectaba. Más patente es el caso de los freires fugitivos que, con bienes pertenecientes a la orden, parecen huir, obteniendo el mayor provecho posible de un edificio comunitario cuya cohesión amenazaba con romper inestables equilibrios. Pero más significativo que todo ello es la paulatina creación de un sistema racionalizado de encomiendas territoriales que, a partir de esas mismas fechas - las de la segunda mitad del siglo XIII-, se consolida como fruto de un gran pacto que, individualizando rentas y derechos, a todos acaba satisfaciendo. En efecto, no parece que sea discutible que la creación de la mesa maestral, producto de una conflictiva gestación que acabaría incrementando el margen de maniobra del titular de la orden, fue posible gracias a una amplia «negociación» que permitió a los freires caballeros obtener, en justa contraprestación, parcelas de responsabilidad jurisdiccional y directas fuentes de ingreso individualizado. De lo que no nos cabe duda es que fue durante el maestrazgo de Pedro Ibáñez y de su inmediato sucesor, Juan González, cuando queda definitivamente pergeñado el mapa comendatario de los calatravos. ${ }^{69}$

\section{El decisivo gobierno de Pelayo Pérez Correa, maestre de Santiago (1242-1275)}

La crisis que la orden de Calatrava sufrió durante el gobierno de Pedro Ibáñez, anunciadora de importantes transformaciones estructurales y responsable última de la consolidación institucional del maestrazgo, cuenta con un significativo paralelo - aunque diverso en algunas de sus características- en el largo gobierno del maestre santiaguista Pelayo Pérez Correa (1242-1275). También él sufrió la contestación de su orden bajo diversas manifestaciones, pero también él supo sobreimponerse a ellas, aunque en su personalizado diseño de gestión no figurara una estrecha y estratégica alianza con la monarquía. Su fuerza, de hecho, consistió en construir con éxito, aunque en medio de una estrepitosa oposición, una consistente mesa

\footnotetext{
${ }^{69}$ Aunque es evidente la existencia de comendadores perfectamente documentados con anterioridad a las décadas centrales del siglo XIII, no lo es menos su inconsistente carácter institucional, su escasa proyección como administradores de auténticos señoríos territoriales y su frecuente transitoriedad al frente de demarcaciones de coyuntural interés y de muy cambiante base material. Sobre el particular, vid. C. de AYALA, Comendadores y ecomiendas. Orígenes y evolución en las órdenes militares castellano-leonesas de la Edad Media, en "III Encontro sobre las Ordens Militares", Palmela, 1998 (en prensa).
} 
maestral, explicación de conflictos y clave para su propio sostenimiento. La evolución del modelo santiaguista hacia la cristalización institucional de sus estructuras se nos presenta, en este sentido, limpia de interferencias o, si se quiere, en estado más puro.

\subsection{Contestación y revueltas en la orden}

Intentaremos a continuación presentar de manera sucinta los hechos y proceder a una interpretación de los mismos que, como veremos, no diferirá en sus líneas fundamentales de la efectuada hace un momento en relación a la orden de Calatrava. La crónica santiaguista de los comendadores Orozco y Parra, redactada como sabemos a finales del siglo XV, nos informa que durante el gobierno de Pelayo Pérez, el comendador mayor de la orden y su sucesor en el maestrazgo, Gonzalo Ruiz Girón, junto con el comendador mayor de Segura y los trece, lo depusieron de su dignidad aduciendo que era dilapidador y que el maestrazgo no era perpetuo. Los rebeldes no se atuvieron a criterios formales en su proceder y el maestre, que había acudido al papa Inocencio IV en defensa de sus derechos, fue restituido en la dignidad maestral recibiendo además dos bulas de apoyo: por la primera el papa disponía el carácter perpetuo y no temporal de la dignidad maestral de la que, por otra parte, en ningún caso podría ser depuesto su titular sin una escrupulosa observancia de los procedimientos que necesariamente pasaban por una comparecencia explicativa del maestre recusado; por la segunda bula, el Papa otorgaba prioridad al criterio maestral a la hora de designar treces si es que entre éstos y el maestre no se producía una coincidencia plena al respecto ${ }^{70}$.

La interesante información que ofrecen los primitivos cronistas de la orden cuenta con evidente, aunque parcial, respaldo documental: en febrero de 1246 el papa Inocencio IV expedía bula a favor del maestre aclarando algunos de los extremos contenidos en otra de su predecesor Inocencio III de 1210 en materia de elección de maestres y treces $^{71}$. En resumen, el contenido de la bula era el siguiente:

\footnotetext{
${ }^{70}$ Orozco-Parra, Historia de la Orden, p. 370. El moderno editor de la obra nos da el nombre de Pedro Núñez de Guzmán como el del rebelde comendador de Segura, más tarde comendador mayor de León.

${ }^{71}$ Bulario de Santiago, p. 167; QUINTANA, Inocencio IV, I, pp. 283-284, doc. 254.
} 
-El maestre elegido por los trece freires, aunque directamente dependiente de la Iglesia romana, debía indudablemente ser considerado perpetuo y no temporal, al igual que el resto de los prelados superiores que son creados mediante elección.

-Como quiera que existen causas para la remoción de un maestre - su carácter inútil o pernicioso-, éstas deben mostrarse y ser probadas con todas las garantías. Un maestre no confeso y legalmente convicto, en ningún caso puede o debe ser removido por la voluntad de los trece o de la mayor parte de ellos.

-Debía considerarse maestre inútil aquél que por enajenación mental o por trastorno de los sentidos no pudiera, de manera irreversible, procurar beneficios a la orden; sería maestre pernicioso quien enajenara castillos y heredades y gastara injustificadamente los bienes de la orden.

-Finalmente, y en relación a la designación de treces, el maestre, caso de fallecimiento o cese por culpa grave de alguno de ellos, podría proceder a su designación con el acuerdo de sólo una parte del estamento afectado si es que no le parecía conveniente acudir a los restantes o a su mayor parte.

Se trataba de todo un balón de oxígeno para un maestre cuyas tempranas ansias de protagonismo institucional y de autoritario personalismo debieron despertar algo más que recelo entre los freires santiaguistas. Los rumores de una eventual y forzada destitución del maestre, traducidos en tentativa, no harían sino recrudecer sus tendencias autoritarias, consciente como era del apoyo pontificio, y no pocos freires santiaguistas empezaron a mostrar su descontento abandonando la orden. Este recurso de contestación era relativamente frecuente. Lo hemos visto en el caso de los calatravos y, en este momento, no debió ser menos espectacular en el ámbito santiaguista: entre 1245 , en cuyo primer semestre debió producirse la tentativa antimaestral, y 1247, al año siguiente de la decisiva bula que acabamos de comentar, la fuga de caballeros revestiría cifras preocupantes. De otro modo no se explica que el maestre acudiera al Papa, su fiel valedor, para poner coto a la situación. Inocencio IV no dudó en movilizar a obispos y reyes para que colaboraran con el maestre en evitar la sangría ${ }^{72}$. Conocemos el nombre de

\footnotetext{
${ }^{72}$ De 28 de agosto de 1245 datan las instrucciones dadas a arzobispos y obispos españoles para que, a instancias del maestre santiaguista, procedan a la excomunión de los freires que habiendo abandonado la orden, vagan ignominiosamente por el mundo con gran peligro para sus almas. Pocos días después, el 2 de septiembre, el papa apela al consilium, auxilium et favorem
} 
alguno de los caballeros huidos, y no sería descabellado pensar en su correspondencia con algún líder de la revuelta antimaestral de $1245^{73}$.

Pero no fue la crisis de ese año la única que estalló en manos del maestre Pelayo Pérez durante su larga gestión al frente de la orden. Probablemente mayor gravedad revistió la que iniciada en 1263 se prolongaría en los primeros meses de 1264. En este momento la crisis afectó al conjunto orgánico de la institución provocando la ruptura del maestre con la rama clerical de la orden, el enfrentamiento con los trece y una generalizada inestabilidad que no sólo obligó a intervenir al Papa sino también, y a instancias de este último, al propio rey de Castilla. La apropiación de diezmos por parte del maestre fue la chispa que generó el fuego. El prior de Uclés se opuso al abusivo intervencionismo del maestre en la gestión de las rentas diezmales y ello provocó su arbitraria destitución ${ }^{74}$. No fue éste más que uno de los frentes que se abrieron en seguida entre el maestre y su orden. Varios treces fueron destituidos por oponerse a la política maestral y el descontento entre los freires se hizo cada vez mayor. El papa Urbano IV hubo de intervenir. A comienzos de 1264 restituía en su dignidad al prior injustamente destituido, sin que las protëstas del procurador maestral

que le deben los reyes de Aragón y Portugal para solicitarles apoyo en el mismo sentido. Idéntico contenido encontramos en una nueva carta pontificia de 18 de septiembre dirigida en este caso al rey de Navarra. Finalmente, en septiembre de 1247, el Papa recuerda a los distintos prelados su obligación de recriminar y, en su caso, excomulgar a freires rebeldes y secularizados que, sin embargo, no dejaban de detentar ilícitamente oficios y encomiendas. Bulario de Santiago, pp. 140, 141, 165 y 173. QUINTANA, Inocencio IV, I, docs. 167, 175, 176 y 451.

${ }^{73}$ El 15 de mayo de 1248 el papa Inocencio IV ordenaba readmitir en la orden de Santiago al miles Pedro Núñez, que la había abandonado animi levitate (Bulario de Santiago, p. 174; QUINTANA, Inocencio IV, II, pp. 494-495, doc. 524). Se trata probablemente de Pedro Núñez de Guzmán, comendador de Segura y luego comendador mayor de León, que figura entre los cabecillas de la revuelta antimaestral, según el testimonio de Orozo y Parra (vid. supra $\mathrm{n}$. 70).

${ }^{74}$ Dos bulas de 30 de enero de 1264 nos informan del contencioso. En la primera, el Papa recuerda la práctica reglar de la orden en materia de diezmos, su preceptivo cobro por los freires clérigos a partir del trabajo y bienes de los freires seculares, su inversión en libros, ornamentos litúrgicos y mantenimiento de los propios clérigos, y distribución del sobrante entre los pobres según provisión del maestre. Pues bien, dicha práctica era ahora impedida por este último que desde hacía varios años venía apropiándose del conjunto de la renta. El Papa ordena su restitución a los clérigos. Bulario de Santiago, p. 201; I. RODRíGUEZ R. DE LAMA, La documentación pontificia de Urbano IV (1261-1264), Roma, 1981, pp. 236-237, doc. 158.

La segunda bula venía a confirmar una antigua sentencia que, ya sobre la misma materia -el problema no era obviamente nuevo-, había dictado èl cardenal y legado apostólico Juan en 1228. Bulario de Santiago, pp. 201-202; el texto de la sentencia ibid., pp. 88-89; RODRÍGUEZ DE LAMA, Urbano IV, pp. 237-238, doc. 159. 
pudieran impedirlo ${ }^{75}$. Desde un moderado eclecticismo no incompatible con la firme voluntad de poner fin a una crisis que podía llegar a cuestionar el principio de autoridad entre los santiaguistas, el pontífice confirmaba en todos sus extremos la doctrina tradicional de la orden en materia de elección y destitución de maestres, signo inequívoco del recrudecimiento de rumores sobre un posible recambio en la cúpula del poder santiaguista ${ }^{76}$. Pero al mismo tiempo daba en esta ocasión su apoyo a los inquietos treces no autorizando su arbitraria sustitución sin el acuerdo corporativo del conjunto $^{77}$; de este modo, la Sede Apostólica cambiaba sensiblemente su postura respecto a la de Inocencio IV que, autorizando los recambios únicamente con el acuerdo parcial o minoritario de la corporación, se había mostrado excesivamente favorable al autoritario poder del maestre.

No parece, sin embargo, que Pelayo Pérez recogiese entonces el mensaje papal: la oposición de algunos treces había provocado su destitución por desacato al maestre y su sustitución por personas afines, y ello obligó a una nueva intervención del pontífice que en abril de 1264 recordaba al maestre la alta función consultiva que correspondía a los trece $^{78}$, y aunque confirmaba los ceses y nombramientos que había efectuado y que constituían una auténtica remodelación del órgano elector, le instaba a que no procediese en forma alguna contra los destituidos con motivo de la pasada desobedien$\mathrm{cia}^{79}$. Para entonces, el Papa ya había movilizado al rey Alfonso X, y no sin subrayar el valor de la monarquía como eficaz protector de la orden amenazada de ruina, le pedía que ayudase al maestre a mantenerse al frente de su dignidad cuestionada por la intolerable insolencia de algunos de sus

${ }^{75}$ Bulario de Santiago, p. 202; RodRígUeZ DE LAMA, Urbano $I V$, p. 243, doc. 164-b (el 164 , p. 242 , es una versión incompleta del anterior).

${ }^{76} 1264$, febrero, 1. Orvieto. Bulario de Santiago, pp. 202-203; ROdRígueZ DE LAMA, Urbano IV, pp. 244-245, doc. 165.

${ }^{77}$ Ya el 12 de enero de aquel año de 1264 el Papa se había pronunciado sobre el particular (RodRíGUEZ DE LAMA, Urbano IV, p. 213, doc. 143). Lo volvió a hacer el 1 de febrero incluyendo, además, disposiciones sobre la normalización de las reuniones capitulares y, tal y como acabamos de ver, un recordatorio sobre las circunstancias de una eventual remoción del maestre (vid. nota anterior).

78"... qui Magistro, cum opus est, in consilio et dispositione Domus assistunt". 1264, abril, 5. Orvieto. Bulario de Santiago, p. 205; RODRÍGUEZ DE LAMA, Urbano IV, p. 293, doc. 204-a. Esa misma expresión la encontramos ya en bulas anteriores como las citadas de enero y febrero.

${ }^{79} \mathrm{Ya}$ en la citada bula de 12 de enero de 1264 se contiene la información sobre los cinco treces fallecidos, así como los que por su rebeldía fueron depuestos por el maestre. Fue, por tanto, en 1263 cuando también se produjo el abierto enfrentamiento entre treces y maestre. 
súbditos $^{80}$. La iniciativa conciliadora de Urbano IV llegó también al conjunto de los miembros de la orden a quienes exigió que mostrasen la debida obediencia hacia su maestre ${ }^{81}$.

\subsection{Circunstancias explicativas}

La segunda gran ofensiva de la orden frente al poder centralizador de su maestre pudo ser neutralizada, pero sus consecuencias no dejarían de sentirse a corto plazo. ¿Cuáles son las razones que explican esta tensa relación jalonada por dos críticos episodios? Hemos insistido vagamente en el autoritarismo de Pelayo Pérez Correa, en sus prácticas de gestión personalista. Todo ello se ajusta al modelo de un maestre que no dudó en explotar propagandísticamente la identificación de su imagen con el sagrado monarquismo del bíblico rey David ${ }^{82}$. Pero las razones concretas de tan críticos enfrentamientos son hasta cierto punto fácilmente reconstruibles.

Si atendemos al relato cronístico de Orozco y Parra, son dos los argumentos esgrimidos para explicar la primera de las crisis documentadas a lo largo del gobierno de Pelayo Pérez Correa: su carácter dilapidador y su deseo de perpetuarse al frente de la institución. El gran argumento -al menos el más explícito- de la segunda de las crisis es la apropiación maestral de diezmos. En ambas circunstancias, por otra parte, encontramos implícito el abusivo tratamiento del maestre en materia de nombramiento y cese de los trece, es decir, los integrantes de una de las más importantes y decisivas instituciones de la orden. Todo ello obedece a un mismo común denominador, un deseo de fortalecimiento de la dignidad maestral, convertido en práctica a través de tres expedientes: conversión de la institución en vitalicia, libertad de maniobra en materia de nombramientos y amplia capacidad de gestión en lo tocante a recursos económicos. Este último aspecto, traducido en enajenaciones ${ }^{83}$ e indebida apropiación de

${ }^{80} 1264$, abril, 1. Orvieto. Bulario de Santiago, pp. 204-205; RodRíguez DE LAMA, Urbano $I V$, p. 290, doc. 201. Existe una carta anterior (1264, febrero, 20. Viterbo) enviada por el Papa al rey sobre el mismo asunto (Bulario de Santiago, pp. 203-204; RODRíGUEZ DE LAMA, Urbano IV, pp. 256-257, doc. 175).

${ }^{81}$ Bulario de Santiago, pp. 205-206; Rodríguez DE LAMA, Urbano IV, p. 294, doc. 204-b.

${ }^{82}$ Ayala, Maestres y maestrazgos en la Corona de Castilla (en prensa).

${ }^{83} \mathrm{La}$ estricta regulación de enajenaciones por parte de cualquier responsable de la orden y del maestre en particular, es un permanente caballo de batalla de los establecimientos santiaguistas. Significativamente los de 1265 , los inmediatamente posteriores a la crisis de 1263 
rentas, constituye el antecedente inmediato a la creación de recursos propios ligados formalmente al titular de la institución, era, en definitiva, el tanteo preparatorio para la constitución de la mesa maestral, sobre cuyo firme soporte, y sólamente sobre él, podría erigirse un fuerte poder institucional de corte inequívocamente monárquico.

En efecto, los primeros testimonios sobre la existencia de la mesa maestral santiaguista datan de los años inmediatamente posteriores y fueron el resultado - lo mismo vimos para Calatrava - de una tensa lucha por el reparto de competencias y recursos que enfrentaba al maestre con un fuerte estamento de freires clérigos y caballeros, y es que los hábitos e inclinaciones señoriales de estos últimos definían perfiles cada vez menos proclives a un disciplinado sometimiento reglar. Es un fenómeno común - ya lo hemos visto- a las corporaciones eclesiásticas de mediados y segunda mitad del siglo XIII, y es, en definitiva, inevitable manifestación de tendencias sociales más profundas. Un texto tardío pero muy expresivo, contenido en los establecimientos promulgados en 1440 por el infante don Enrique, define mejor que cualquier otro argumento cuál era la situación entonces y con qué dificultades hubo de enfrentarse el maestre Pelayo Pérez Correa: "... [en aquel tiempo] nuestra Orden e religion padeçio muchos daños e al dicho maestre vino grande detrimento por los caballeros de nuestra Orden en aquella sazon que eran de gran linaje e non le querien dar las fortalezas que tenian quando el maestre gelas demandava..." ${ }^{84}$.

Que los caballeros de la orden, encastillados en unas fortalezas que consideraban propias, fueran de gran linaje explica las reticencias hacia un programa centralizador que tendía a la fundamentación de un sólido poder maestral, necesariamente neutralizador del de los freires. También aquí, como en el caso de Calatrava, la tensión se resolvió en acuerdo tácito: el maestre podría acotar a su favor un específico patrimonio, pero los freires obtendrían encomiendas y beneficios cuya dimensión patrimonial pudiera compensar el acrecentamiento del poder maestral. El reparto tuvo formalmente lugar en el capítulo general celebrado en Mérida en 1274 , el último

1264, prescriben "que ningund maestre nin comendador nin otro freyle de nuestra Orden que non pueda dar heredad de nuestra Orden nin pagarla nin venderla a menos de Cabildo General". $\mathrm{BN}, \mathrm{Ms} .8 .582$, fol. $65 \mathrm{r}$.

${ }^{84} \mathrm{BN}$, Ms. 8.582 , fols. 135 v-136 r. Entre otras, hay versiones del texto de los establecimientos de don Enrique en dos códices del AHN (512 y 668) y uno de la Biblioteca del Real Monasterio de El Escorial (b.IV.7). 
de los que presidiera Pelayo Pérez Correa. Se acordaba entonces que el maestre aya por sus camaras sendas encomiendas en Castilla, Campo de Montiel, León, Portugal y Aragón, mientras que el resto de las mismas serían entregadas "con los derechos que les pertenesçen a los freires" ${ }^{85}$.

\section{Huellas de crisis durante el gobierno de García Fernán- dez, maestre de Alcántara (1254-1284)}

Sobre la orden de Alcántara no contamos con información que nos permita reconstruir el proceso constituyente de la mesa maestral en el marco de una clara redefinición institucional del maestrazgo. No detectamos en ella la evolución crítica anunciadora de tan decisivas transformaciones que hemos visto respecto a otras órdenes $\mathrm{y}$, sin embargo, no sería difícil ubicar los acontecimientos conducentes a esa misma realidad en fechas semejantes que, en este caso, se corresponderían con el largo gobierno de García Fernández (1254-1284), séptimo maestre de la orden.

De esos acontecimientos no tenemos ningún testimonio documental inequívoco, pero pensamos que es razonable establecer posibles paralelismos entre la realidad alcantarina y, de modo muy especial, la evolución ya estudiada de la de Calatrava. A la afinidad constitutiva de ambas órdenes, que ya de por sí podría explicar un trasvase o identificación de procesos, hay que añadir una serie de circunstancias que acentuarían el hipotético paralelismo entre ambas instituciones.

Para empezar, y como ya sabemos, el maestre calatravo Pedro Ibáñez, inicial responsable de las transformaciones operadas en su orden, provenía de la de Alcántara, y cuando en 1254, y por voluntad regia, pasó a gobernar los destinos de los freires calatravos, dejaba tras sí un sucesor no menos leal a la causa monárquica que él mismo. En efecto, García Fernández fue, como Pedro Ibáñez, un fiel colaborador de Alfonso X y de sus objetivos de gobierno, y, como sabemos, fue, al abrigo de esos objetivos y aprovechando el eficaz apoyo de la corona, como Pedro Ibáñez puso en

\footnotetext{
${ }^{85} \mathrm{BN}$, Ms. 8.582, fol. 45. El esquema no aparece aún con claridad en los arrendamientos generales de rentas provenientes del señorio santiaguista de los reinos de Toledo y Murcia de los años 1272 y 1273 . En ellos el maestre ha diseñado ya una general distribución geográfica por bastimentos que, con exclusión de rentas priorales, integran "derechos que nos e nuestra orden y avemos e devemos aver", sin aludir en ningún caso a encomiendas de cámara o de tipo ordinario (LomAX, La Orden de Santiago, pp. 270-275, docs. 31-33).
} 
marcha la maquinaria reforzadora de la propia esencia de la dignidad maestral. Cabría pensar, pues, que García Fernández, siguiendo el modelo de alianza con el trono del maestre calatravo - distinto en este sentido al santiaguista, más independiente y señorializado-, podría haber puesto en marcha una serie de cambios conducentes al reforzamiento de su poder y a la transformación de la naturaleza institucional del maestrazgo.

Nos movemos en el terreno de la pura conjetura, pero, aunque sin salirnos de ella, cabría aducir algún dato que permita elevar a la categoría de hipótesis lo que por ahora no es más que una posibilidad indemostrable. Como sabemos, la guerra civil que pone fin al reinado de Alfonso $\mathrm{X}$ movilizó a prácticamente todas las órdenes militares en contra del rey y a favor de la causa sanchista, de manera muy especial a las de Santiago y Calatrava, en las que el proceso de transformación de sus maestrazgos se había completado ya a través de la consolidación de sus respectivas «oligarquías comendatarias». No olvidemos que el estandarte sanchista cobijaba los intereses de las más conservadoras aristocracias señoriales frente al autoritarismo centralizador que durante tanto tiempo había caracterizado al gobierno de Alfonso X.

La excepción en este alineamiento de las órdenes militares lo constituye la de Alcántara, quizá más bien la del fiel alfonsino García Fernández, su maestre ${ }^{86}$. Pues bien, algún testimonio indirecto nos permite detectar un cierto descontento entre los freires alcantarinos contra su maestre que, en el contexto de la guerra civil castellana, bien podría relacionarse con posiciones revanchistas, no muy bien definidas, frente a un autoritario gobierno maestral. Si estuviéramos en lo cierto, podríamos constatar un posible, y en cualquier caso retrasado, paralelismo con lo acontecido en relación a los maestres Pedro Ibáñez y Pelayo Pérez Correa, responsables ambos del inicio de las profundas transformaciones operadas en sus respectivas órdenes. ¿Pudo el alcantarino García Fernández, aprovechando el apoyo regio, proceder a un reforzamiento de su propia dignidad siguiendo, en este sentido, más el modelo calatravo que el santiaguista?

Analicemos brevemente los testimonios indirectos a los que aludíamos hace un momento. Los dos que citaremos provienen de la crónica del casi siempre bien documentado Torres y Tapia. El primero es la orden

\footnotetext{
${ }^{86}$ Pese a que algunos datos cronisticos pudieran hacer pensar en una «intermitente alteración" de la misma. Ayala, Monarquía y órdenes militares, pp. 463-464.
} 
que en 1282 Alfonso X dió al maestre de Alcántara para que combatiese al infante don Sancho desde todas las villas y fortalezas de su jurisdicción, una orden que el maestre se apresuró a cumplir haciendo un llamamiento a todos los castillos de los partidos de La Serena y de Alcántara, "que había muchos y muy fuertes", de todos los cuales "hicieronle pleyto omenage sus Comendadores y Alcaydes, que estarian siempre por el Rey D. Alonso, y a las Villas y Lugares mandó tubiesen su voz"87.

La movilización de todos los castillos a favor del rey nos recuerda, salvando distancias y circunstancias, la «entrega» que Pedro Ibáñez hizo de las fortalezas calatravas al mismo Alfonso X en 1260. Probablemente no debamos interpretar esa "entrega" de castillos de modo muy distinto a un compromiso sin condiciones ni contraprestaciones de disponibilidad de los mismos a favor del rey. Exactamente lo mismo que hizo García Fernández exigiendo de cuantos comendadores y alcaides se hallaban al frente de las fortalezas alcantarinas una fidelidad incondicional a Alfonso X mediante un personalizado pleyto omenage.

No sabemos si estos comendadores y alcaides, representantes sin duda de la señorializada oligarquía alcantarina, respondieron tan de mala gana a su maestre como sabemos lo hicieron los calatravos en 1260 y los santiaguistas en fecha indeterminada, según tardío testimonio del maestreinfante don Enrique. No debemos olvidar que las fortalezas eran el símbolo de un poder que, en clave señorial, traducía ya en ese momento las ansias patrimonializadoras de los freires.

Efectivamente no conocemos esa respuesta a nivel general, pero sí la del más significativo, y quizá por ello representativo, de los comendadores responsables de fortalezas. Nos referimos a Fernando Páez, futuro maestre y ahora comendador mayor de la orden, que abrió el castillo de Alcántara al infante don Sancho y sus seguidores, desoyendo clamorosamente la iniciativa maestral. $\mathrm{Y}$ así enlazamos con el segundo de los datos de Torres y Tapia a los que aludíamos hace un momento: aprovechando la postura del comendador mayor, el infante rebelde provocó la destitución de García Fernández y su sustitución por Fernando Páez, haciendo que "algunos

\footnotetext{
${ }^{87}$ TORRES, Crónica, I, p. 410. La Crónica de Alfonso $X$, aunque de forma poco explícita, recoge la noticia de que el maestre de Alcántara hacía la guerra al infante don Sancho desde los castillos de su jurisdicción, "porque tenía voz del rey don Alonso" (Crónicas de los Reyes de Castilla, ed. C. Rosell, I, Madrid, 1953, p. 62).
} 
Freyles Caballeros, sus aficionados, le eligiesen y diesen obediencia"88. Se trata de una conjetura del cronista basada en unos «memoriales antiguos" y en un documento del archivo alcantarino en el que el infante don Sancho hace merced a la orden de un privilegio en el que figura Fernando Páez como maestre antes de producirse el fallecimiento de García Fernández. ${ }^{89}$

Si los datos y apreciaciones de Torres y Tapia son correctos, estaríamos ante toda una facción contraria al maestre legítimo que, a raíz del siempre sensible tema de la disponibilidad de fortalezas, dejaría traslucir un descontento latente en forma de rebelión abierta. No sabemos desde qué momento vendría arrastrándose ese descontento, pero es el momento de completar el cuadro aludiendo a otro hecho que se produjo también durante el gobierno de García Fernández, con anterioridad a la guerra civil de 1282, y que guarda un paralelo extraordinario con otro ocurrido en el conflictivo maestrazgo del calatravo Pedro Ibáñez. En 1279 el rey había entregado al maestre alcantarino las villas y castillos fronterizos de Morón y Cote, con la condición de que a la primera de estas localidades, rebautizada como Buenaventura, se trasladara el convento mayor de la orden ${ }^{90}$. Se trata exactamente de la misma operación que 15 años antes había intentado el rey respecto a Calatrava con Osuna. Ya vimos en su momento que esta última iniciativa obedeció a los intereses de la corona, que tuvo lugar gracias a la servil fidelidad del maestre Pedro Ibáñez y que con toda probabilidad no fue del agrado de los freires. Los mismos argumentos y comentarios son aplicables al caso de Morón: planes reales de doble objetivo - defensa fronteriza y desarticulación de la base fundiaria de la orden- y un maestre complaciente. La oposición de los freires explicaría también aquí que el proyecto fracasara, y todavía más lo explica que la donación fuera probablemente revocada por Sancho IV antes de producirse el fallecimiento del alfonsino García Fernández ${ }^{91}$, y reasumida por el mismo monarca un año después, pero a favor de su aliado el maestre Fernando Páez, sin alusión alguna al escabroso tema del traslado conventual ${ }^{92}$.

\footnotetext{
${ }^{88}$ TORRES, Crónica, I, p. 412.

${ }^{89}$ Se trata de la confirmación de la concesión a la orden de 3.800 mrvs. sobre la martiniega de Ciudad Rodrigo, concesión efectuada por Alfonso IX y revalidada por Fernando III y el propio Alfonso X (TORRES, Crónica, I, p. 412).

${ }^{90}$ GonZÁlez, Diplomatario, pp. 478-480, doc. 453.

${ }^{91}$ TORres, Crónica, I, p. 421.

${ }^{92}$ M. GaIBroIS, Sancho IV de Castilla, III, Madrid, 1928, p. LX, doc. 92.
} 
Si unimos todos estos datos, dispersos y no siempre bien contrastados documentalmente, estaríamos, pues, ante un proceso crítico hasta cierto punto paralelo a los que hemos visto respecto a calatravos y santiaguistas. Si analizásemos otras variables - grado de consolidación de encomiendas y verdadera articulación de su red-, llegaríamos ciertamente a la conclusión de que, en este sentido, la segunda mitad del siglo XIII, que en el caso de Alcántara casi corresponde al largo maestrazgo de García Fernández, fue decisiva a la hora de redefinir la estructura institucional y el nuevo modelo de reequilibrio de poder en el seno de la orden.

\section{CONCLUSIÓN}

Cuando en el transcurso del último cuarto del siglo XIII se consuma el proceso de creación de las respectivas mesas maestrales - la plenitud de su desarrollo no se producirá hasta más de un siglo después-, se puede ya establecer una valoración general que nos sirva, a modo de conclusión, para poner fin a estas líneas.

La creación de las mesas maestrales constituye la condición necesaria para la consolidación institucional de quienes encarnan la máxima dignidad en cada una de las órdenes. Este hecho les confiere capacidad de maniobra respecto a freires y vasallos dependientes, y autonomía y personalidad política en relación a jurisdicciones foráneas. Les proporciona, en definitiva, fuerza, aquélla que en el futuro dificultará el cuestionamiento de su carácter vitalicio y que les permitirá rodearse de un completo y eficaz aparato de poder.

Pero este acabado diseño de los maestrazgos contará como inevitable contrapartida con una realidad tan paradójica como absolutamente comprensible: el fortalecimiento del maestre va acompañado del de los freires caballeros - también el de las categorías priorales de los clérigos- que, como oligarquía efectiva de poder, no rebaja sus ansias de protagonismo respecto a etapas anteriores, pero viéndose obligada ahora a encauzarlas en un equilibrado juego de compensaciones mutuas cada vez más al margen de aventuras cismáticas o presiones violentas. Antes de que finalizara el siglo XIII, los freires, coherentes en sus planteamientos, muestran con absoluta 
claridad sus apetencias y objetivos: mayor responsabilidad en la toma de decisiones ${ }^{93}$ y retención vitalicia de encomiendas y beneficios ${ }^{94}$.

Pero ninguna de estas realidades supone, como pudo pensarse en algún momento de tensión, que las órdenes militares se descomponían hasta su práctica disolución. Muy al contrario, lo que asistimos al filo del 1300 es a procesos de maduración institucional que las convierten en articulados organismos, clásicos en sus perfiles y eficaces en su modélica y unitaria proyección social que sólo alcanzaba pleno sentido en la complementaria integración de sus miembros, y es que, como afirmaba un interesado tratadista de la orden de Santiago, "el maestre e la horden y el pueblo son tres cosas que valen poco la una sin la otra"95.

\section{RÉSUMÉ}

Le XIII ${ }^{\text {ìme }}$ siècle constitue pour l'évolution des Ordres Militaires une période clef. Durant cette période ont lieu en effect les processus de transformation institutionnelle qui permirent de dessiner leur image classique. Dans cet article, nous avons tenté de présenter ce processus sous l'aspect de l'évoliution concret du maestrazgo, de sa consolidation institutionnelle et matérielle. L'objet de l'analyse parte plus particulièrement sur les circonstances complexes qui accompagnent dans les Ordres Militaires de Santiago, Calatrava et Alcantara la genèse de leurs respectives mensas maestrales.

\section{SUMMARY}

Thirteenth century is a main period for evolution of Military Orders. During its development come about institutional changes that are taking shape its typical image. This

\footnotetext{
${ }^{93} \mathrm{El}$ acéfalo capítulo general santiaguista celebrado en Mérida el 31 de marzo de 1275 , semanas después de la muerte de Pelayo Pérez Correa, en un significativo gesto, más que simbólico, arrebataba el sello capitular de manos del maestre para entregarlo a los trece. En realidad, todo el breve articulado de los establecimientos allí promulgados constituyen un auténtico programa de gobierno oligárquico para el regimiento de la orden, un programa que por imperativo capitular habría de ser jurado por el maestre "que primero fuere" (BN, Ms. 8.582 , fols. $66 \mathrm{v}-67$ ).

${ }^{94}$ Desde 1275 las pueblas efectuadas por los freires santiaguistas se convertían en tenencias vitalicias para los comendadores responsables (Bulario de Santiago, pp. 220-221). Algunos de ellos, poco antes de 1299, llegaron a amenazar con la entrega de fortalezas fronterizas a los musulmanes si no les concedian perpetuo retinendas casas y encomiendas (Ibid., p. 244).
}

${ }^{95}$ D.W. Lomax, Pedro López de Baeza. "Dichos de los Santos Padres" (siglo XIV)", en "Miscelánea de Textos Medievales", 1 (1972), p. 161. 
article tries to offer aforement process dealing with specific evolution of mastership and its institutional and physical consolidation. The article studies specially the complex circumstances that accompany, in the Military Orders of Santiago, Calatrava and Alcántara, the beginning of their mesas maestrales. 